\title{
EENIGE MEDEDEELINGEN OVER DE ALFOEREN VAN HALE-MA-HÈRA.
}

DOOR

C. F. H. CAMPEN.

I.

Woningen der klfoeren. - De vier typen. - Strandwoningen. - Aanleg der dorpen. - De Saboea's. - Bouworde. - De Kokkiroba's. - De Wongi-ma-falla's. - Onderhoud der huizen. - Gebruiken bij den bouw.

$$
\text { (Plaat 1.) }
$$

De woningen der Alfoeren, altijd van hout, dan wel ran lichtere materialen vervaardigd, zijn over het geheele eiland weinig eenvormig; men zoude ze echter in hoofdzaak kunnen onderscheiden in twee groote klasser, namelijk die welke vluk op den grond en die welke op palen boven den grond gebouwd zijn.

Deze twee soorten zijn echter niet een bepaalde eigenaardigheid ran verschillende stammen, want men vindt ze over geheel Hale-ma-hera, soms zelfs in één en hetzelfde dorp bij elkaâr, zonder dat daarvoor eenige anleidende oorzaak bestaat.

Ook de inwendige bouworde der woningen, de gekozen bouwstoffen, hare grootte, enz. hangen geheel af ran den ijver, de geschiktheid en het aantal zielen van het daarin vertoevend huisgezin. Buitendien verliezen vele woningen haar oorspronkelijken vorm door het bijbouwen.

Gevoegelijk echter en zonder de waarheid te kort te doen kan men spreken van vier verschillende typen, namelijk:

10. de Galellasche type: altijd op den grond gebouwde woningen, waarran de projectie der stijlen een kruis en de rand. van het dak een ietwat onregelmatigen achthoek of een aan de vier hoeken afgeknot langwerpig vierkant vormt (fig. I.)

De ruimte-verdeeling is de volgende: een groot vierkant, in het midden, al dan niet afgeschoten, dienende hetzij tot magazijn, hetzij tot feestplaats, enz., boven welk vierkant zich een soort van bel-étage, de slaapplaats der jonge meisjes en kinderen, bevindt, een voor de mannen zonder speciale vergunning ongenaakbaar 
en door zware boete gevrijwaard heiligdom; en de overige ruimte is als het ware een rondloopende galerij, waar de lange etenstafels met zitbanken staan en de verschillende kleine afgeschoten hokjes der getrouwden zich bevinden; een der hoeken dient als keuken.

De deuren, beter gezegd, ingangen bevinden zich op de afgeknotte hoeken en zijn meestal twee in getal, dienende de eene meer bepaald voor de mannen, en de andere voor de vrouwen. Soms hebben deze ingangen houten deuren, meestal worden zij slechts des nachts met een atap-schutsel gesloten.

Het geraamte is bijna altijd van licht wit hout en de wandbekleeding altijd van kadoe (atap).

20. de Toebaroesche type (fig. II).

Ook hier zijn de huizen, de uitzonderingen daargelaten, gelijk met den grond gebouwd. Zij bestaan uit een soort van roorgalerij of marguis, een even breede binnengalerij met kamers aan weerszijden en soms ook een smalle afgeschoten achtergalerij, allen naar behoefte met deuren voorzien; in den regel echter heeft elk huis drie deuren: een van voren, een van achteren en een op zij, welke deuren meestal van sassak (gevlochten bamboe) vervaardigd zijn en den vorm van een klep hebben. Over dag opgeslagen en aan een haak opgebangen, worden zij des nachts neergelaten en met een palang pintoe (sluitboom) gesloten.

De wandbedekking wordt in den regel van gespleten bamboe (ploepoeh) vervaardigd, van welk materieel, op de zwaardere stijlen en dakbedekking na, dikwijls het geheele huis in elkaâr is gezet; echter wordt nog wel eens de voorgevel van lichte planken vervaardigd.

30. de Sahoesche type (fig. III), gevormd, als het ware, uit een van planken en balken vervaardigden \pm 1 meter boven den grond staanden stevigen houten kern, meestal omringi door een los uit bamboe vervaardigd gelijkvloers omhulsel, in den regel uit een voorgalerij voor het geheele front van het huis, een keuken en eenige andere kleine kamertjes op de zijde bestaande.

Bij sommige huizen echter ontbreekt deze omgeving geheel, en kan men dan al dadelijk opmerken, dat de eigentlijke vorm der oude Sahoesche huizen een langwerpig vierkant is, dat, behalve een smalle voorgalerij, uit een ruime binnengalerij met een zijvertrek aan weerszijden, bestaat. 
De nieuwere huizen, die meestal slechts uit bamboe vervaardigd zijn, vormen met deze oudere uit stevig hout gemaakte en vaak met snijwerk versierde huizen een droevig contrast, en wijzen op den langzamen achteruitgang der bevolking.

Ten slotte

de $4^{\text {de }}$, de Kausche (Ka-oe, Kahoe)-type (fig. IV).

De woningen in het Kausche binnenland staan wegens de vele overstroomingen en de vochtigheid van den grond allen op $\pm 1.5 \mathrm{M}$. hooge palen; zij hebben allen een breede voorgalerij en bestaan bij een klein huisgezin uit een in tweeën verdeeld binnenhuis met slechts één ingangsdeur, terwijl de grootere huizen in een bimnengalerij met een kamertje aan weerszijden, elk met een afzonderlijken ingang, zịn verdeeld.

Soms vindt men ook kleine achterdeuren en wordt aldaar de meestal in het midden der voorgalerij geplaatste ladder vervangen door een ingekerfden boomstam.

De geraamten der huizen zijn mecstal uit zekor licht en wit hout, lolekko genaamd, dat bijzonder bestand is tegen vocht, vervaardigd en men makt voor de wandbekleeding, behalve van planken van evengemelde houtsoort, ook wel van bamboe, maar meest van kadoe gebruik.

Naast deze huizen vindt men in den regel een klein tot keuken en houtloods dienend gebouwtje (fig. V).

De dakbekleeding van al de vier typen bestaat uit kadoe (atap) en men versiert ze door de nokken aan weerszijden te verlengen en met goemoetoe-kwasten enz. te behangen, dan wel daarin een kaaimansbek of iets dergelijks uit te snijden.

Ook de aan de kanten van het dak uitstekende bamboe's worden meestal als kris- of lanspunten gesneden.

In alle huizen, behalve in de Kausche, waar de vloer tot zit- en slaapplaats dient, vindt men de noodige bamboezen degodego's of rustbanken.

De huizen der bijna altijd aan het strand wonende Tslamsche Alfoeren en verdere Mahomedanen zijn schier overal vervaardigd uit gaba-gaba (bladstengel der sago-palm) en zeer afwisselend van vorm en grootte, meestal bestaande uit een afdak (marguis), een gang met kamers aan weerszijden en een afgesloten achtergalerij, die tevens tot keuken dient; verreweg de meesten echter zijn niets dan kleine vuile krotten.

Een gunstige uitzondering daarop maken de door sommige lieden van Maba, Patani en Weda opgezette woningen, welke 
er met hare dik met kalk besmeerde, tusschen dubbel latwerk opgetrokken muren van opgestapelden koraalsteen als steenen huizen uitzien en door eene voor Halemahera ongekende helderheid en buitengewone zindelijkheid uitmunten.

De Alfoersche dorpen, die dikwijls niet meer dan vier à vijf groote huizen tellen, bestaan soms uit een groot plein van vierkante of langwerpig vierkante gedaante: Kau, Sahoe, enz., waaromheen de huizen gebouwd zijn, soms echter slechts uit een breede straat met huizen aan weerszijden, Tobello, Galella, enz.

Versterkte of omheinde dorpen heeft men niet op Halemahera; meestal schijnen echter oude dorpen in een kom te leggen of wel omringd te zijn door een soort van wal, welke echter niet opzettelijk aangelegd, zijn ontstaan aan een jaren lange ophooping van het om de huizen weggeveegde vuil te danken heeft.

Vele dorpen zijn echter door hunne ligging sterk en de meesten worden omringd door een natuurlijke omheining bestaande uit een dichten gordel van pinang, klappa- en andere vruchtboomen en met làag hout en struikgewas.

In elk dorp staat in het midden de Saboea (fig. VI), een soort van raadhuis, zijnde een groote open loods, dienende tot algemeene verzamelplaats en het geven van feesten en maaltijden; ook in de Islamsche negorijen vindt men hier en daar nog Saboea's als een merkwaardig overblijfsel van het verleden.

Aan deze Saboea's, die door de geheele dorpsgemeente gebouwd en onderhouden moeten worden, legt men veel moeite en arbeid ten koste en velen munten, behalve de meestal sierlijk met hout- en vlechtwerk van bamboe en goemoetoe versierde daken en gevels, van binnen door een rijkdom aan snijwerk uit, welk snijwerk bij de geringe hulpmiddelen en slechte werktuigen, die de Alfoer meestal voor zulk werk bezit, allen lof verdient.

De soms grillig, soms geheel symmetrische en niet zonder smaak gehouwen pilaren, enz. zijn, behalve de vaak zeer kunstig door elkaar gewrongen en soms bepaald schoone arabesken, ook veelal versierd met minder uitmuntende voorstellingen uit het dierenrijk, zooals slangen, schildpadden, vogels en kaaimannen; dikwijls prijken zij ook met sterk ontwikkelde vrouwenborsten en onmogelijke mannetjes, die den krijgsdans beoefenen of jacht op nog onmogelijker wild maken: soms brengt men ook hier en daar houten vogels op, welke aan een uit een stuk hout vervaardigden houten keten hangen. 
De verbinding der dakgebindten gebeurt op Chineesche wijze. Aan de buitenzijde der hoofdpilaren staan kortere en door dwarsplanken met dezen verbonden zijpilaren, dienende om bij feesten de losse tafelbladen te schragen, welke zij-pilaren meestal eindigen in een kegelvormigen knop, die een imitatie der bị de feesten gebruikte rijsthoopen voorstelt.

Elk dorp tracht met zijne Saboea zijn buurlieden den loef af te steken, door haar zoo fraai mogelijk te maken, terwijl men niterst naijverig en nawwlettend is op het punt van imitatie, te meer daar de adat onder zware boete elke nabootsing verbiedt 1.

De Saboea's van Halemahera hebben met gering verschil overal de gedaante van een langwerpig vierkant; aan beide lange zijjen, soms echter ook langs één der of wel de beide korte zijden, zijn losse tafels en vaste ritbanken aangebracht, waarvan de van hout vervaardigde uiteinden voor de hoofden en dorpsoudsten dienen; de bevolking neemt daarop bij feesten volgens den adat plaats overeenkonstig de ligging harer huizen.

Boven de groote in het midden overblijvende ruimte is veelal cen stellage of geestentafel, ma-taba, angebracht, waarop de offeranden voor de geesten worden geplaatst, in welk geval, evenals wanneer sen gedeelte afgeschoten is, de Saboea tevens tot "kokkiroba" of geestenwoning dient.

Onder het dak der Saboea worden ook de Gado's kransen, de wokkabladeren en bamboezen drinkkokers "soppee" als evenveel teekens van platsgevonden krijgstochten opgehangen Ook vindt men daar ter plaatse in den regel een of meer groote trommen of paparokka's, welke dienen om de bevolking bijéén te roepen.

Dient de Saboea niet tot "kokkiroba", dan vindt men naast deze een afzonderlijk klein huisje (fig. VII), meestal uit een voor- en bimengalerij bestaande; welk huisje, behangen met guirlandes van de bladrepen der Sehotakken (arenpalmen) en versierd met snijwerk, dan meer uitsluitend bestemd is tot het vereeren van en offeren aan de geesten der afgestorvene dorpsgenooten en voorvaderen.

Behalve deze kokkiroba's vindt men nog nabij de woningen de veel kleinere geestenhuizen, wongi-ma-falla's, dienende tot verblijf van meer particuliere geesten (fig. VIII), meestal slechts

1 Herhaaldelijk werd door onze bestunrslieden op Halemahera de bandhaving van dezen adat belet en verboden. - Eilieve het Europeesche Patentrecht dan? - - - 
uit een dak op palen met een soort rau verdieping bestaande; maar ook miniatuurhuisjes ter grootte van een jeneverkist dienen tot geestenwoning, welke huisjes dan echter in de woningen bewaard worden.

Eens in het jaar worden volgens den adat alle woningen in de negorij vernieuwd of gerestaureerd; dit geschiedt in den regel, wanneer de padie in de goera's (tuinen) een halve el hoog staat en het onkruid voor het laatst gewied is.

Bij het ontginnen der velden, in 't begin van het jaar, verlaat men namelijk vrij algemeen de negorij en vertoeft alsdan ongeveer drie maanden in de te nidden der soms ver afgelegen goera's opgezette tuinhuisjes, die veelal met wokkabladeren gedekte, min of meer openstande loodsen of schuurtjes. zijn. '

Het vernieuwen der Saboea, wier geheele verwaarloozing den toom der voorvaderlijke geesten opwekt en door deze met zware ziekten, epidemiën, enz. gestraft wordt, geeft altijd aanleiding tot een groot feest.

Nadat ieder met het bij onderlinge afspraak hem toegewezen gedeelte van het houtwerk, enz. gereed is, begint men gezamentlijk met het plaatsen der vier hoofdpilaren, aan den voet waarvan, evenals bij elk nieuw gebouw, vier verschillende plantensoorten begraven worden; meestal is dit cen koenjit-wortel (Curcuma), een gorakka-takje (Zingiber officinale), een gorang koessoe plantje (Nothopanax) en een poelistek (Alstonia). Achtereenvolgens wordt daarop alles in elkaar gezet en gepast; als dit dan op een kleinigheid na gereed is, gaat men gezamentlijk naar het bosch om te jagen, dan wel naar zee om te visschen, terwijl een gedeelte sago gaat kloppen.

Als men genoeg wild of visch bij elkaar heeft, keert men naar de negorij terug; op den daarvoor bestemden dag wordt dan zoogenaamd de laatste hand aan het werk gelegd; de omheining, die als een teeken van het bobosso (verboden) den toegang. belette, wordt even als de omwindsels, die het snijwerk bedekten, afgenomen, de hier en daar met opzet achterwege ge-

1 Dit neemt echter niet weg, dat, daar waar er de hand niet aan gehouden wordt, de zoogenaamde tuinhuisjes langzamerhand vaste woonplaatsen worden en men de hnizen in de negorij stilletjes en ongehinderd vervallen laat. De toestand der meeste dorpen laat dan ook door het slechte bestuur in ' $t$ algemeen zeer veel te wenschen over, en zeer vele, om niet te zeggen de meesten, verkeeren in een schromelijken staat van verval en is de bevolking van Halemahera een heel eind op weg om tot het oorspronkelijke nomaden-leven in de bosschen terug te keeren, zouder dat dit feit eenige aandacht trekt.

4e Volgr. VIHI. 
laten ornamenten, even als de laatste bouten en houten aangeslagen, waarop de Saboea onder de opstijgende geuren van het rookende feestmaal met de noodige offeranden aan de geesten der voorvaderen wordt aangeboden.

Een door dergelijke gebruiken voorafgegaan feest heeft op mindere schaal ook bij het in gebruik stellen eener particuliere woning plaats.

\section{II.}

Huisraad. - Keukengereedschap. - Ameublement. - Gebruik van bamboe en wokka. - De kabila's. - Ornamenten. - Glaswerk. - Voeding. De hoeda. - Aardvruchten. - Groenten. - Dierlijk voedsel.

\section{(Plaat II.)}

Het huisraad der Alfoeren kenmerkt zich door grooten eenvoud en bestaat in de eerste plaats uit eenig keukengereedschap, zooals aarden potten en pannen "bosso" (fig. 1), Marehsch product 1, waarbij soms een ijzeren pan of kwali, "bosso besi " (fig. 2) komt; eenige met snijwerk versierde scheplepels, " iroe " (fig. 3), en roerhouten, "aroe " (fig. 4) met daartoe behoorenden hanger, "ngelle ngelle" (fig. 5); bamboezen vuurtangetjes, "gatta gatta " (fig. 6); eenige waaiers " daho daho" (fig. 7) en blaaspijpen "soempi " (fig. 8); een toestel om klappa's te raspen, "njonitto" (fig. 9) of " gogekke "; eenige aya's zeeften of niroe's (fig. 10a); een blok met stamper, om de rijst te ontbolsteren, "disso " (fig. $10^{\mathrm{b}}$ ); soms ook een aarden vorm om sagobrood te bakken, "forno" (fig. 11 a) en eenige kommen en borden van Europeesch of Chineesch maksel.

Verder bezit bijna iedereen eenige tikars, "djongoettoe " (fig. 11 $1^{\mathrm{b}}$ ), dan wel pandan-matten, "kokoja's" (fig. 12), om daarop te slapen, benevens een paar wandmatten, "lippi's" (fig. 13) en net bewerkte eerematten, "dodigira's" (fig. 13b).

Hoofden en rijke Alfoeren zijn-meestal in 't bezit van eeu bont katoenen gordijn, dat voor hunne door "lippi's " afgeschoten slaapplaats wordt opgehangen; ook ziet men veel gebruik maken van hoofdkussens van kapok, "norra's" (fig. 14)

1 De roode kleiaarde op dit eiland gevonden wordt echter ook op sommige

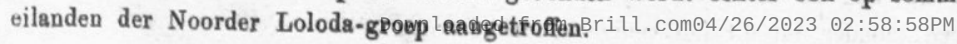


genaamd. Een of meer groote "kabila's" (fig. 15), zijnde doozen van pandan-bladeren en gabagaba-repen vervaardigd, voor het bewaren der beste kleêren, eenige gevlochten protjo's of rijstzakken (fig. 16), twee of meer van de breede bladscheeden der sagotakken vervaardigde "paloedie's" (fig. 17), dan wel eenige gevlochten draagkorven (fig. 18) zijn evenals de noodige houten sago-hamers "nongalo's" (fig. 19) en de koeda-koeda of Alfoersche handploeg (fig. 20) in elk huishouden te vinden.

Verder maakt men gebruik van den bamboe, die in de Alfoersche huishouding een groote rol speelt; zoo worden onze tafels en stoelen door hoogere en lagere bamboezen "dego dego's", rustbanken, vervangen, wier houten hoekstijlen men dikwijls in den vorm van een mensch of menschelijk hoofd en borst uitsnijdt.

Bij of voor elk huis staan verder op een meer of minder net bewerkte stellage, "dango-dango " genaamd, de lange bamboezen, die tot het bewaren van het drinkwater dienen; ook is de bamboe het aangewezen vaatwerk voor den sagoeer, den volksdrank bij uitnemendheid; bịj feestelijke gelegenheden worden deze bamboezen "pondangan" (fig. 21) met allerlei snịwwerk versierd en gesloten met een houten kunstig uitgesneden stop (fig. 22), "baboekka " genaamd.

In de jonge bamboe-geledingen worden de rijst en de aardvruchten, enz. gekookt en kleinere vischsoorten (njaö-ka-amoe, enz.) geroosterd.

De bamboe doet verder dienst als drinkbeker en hoorn, "soppee" (fig. 23), als maat, "koela" (fig. 24), als spaarbus, als stopflesch, als kalkpotje, als kruidhoorn, enz. enz., in 't kort hij is voor den Alfoer onmisbaar.

Ook het blad van de wokka-palm (Corypha) wordt in de Alfoersche huishouding voor verschillende doeleinden gebruikt, b. v. als waterschepper, "sia-sia" (fig. 25), als omhulsel van allerlei pakken, "konjo", als drinkbakje, "bajaai" (fig. 26), als omwindsel der harsfakkels, "salo" (fig. 27), als deksel voor vaatwerk, "boboekka", enz, enz.

Onder het onmisbare huisraad moet ook worden gerangschikt de sirihdoos, "mokkoe-ma-do-daai", ook wel "kabila" (fig. 28) genoemd.

Aan deze sirihdoozen, warin zich de vier ingredienten

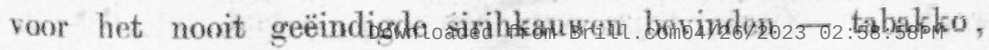


henna (pinang), bido (sirihbloesem) en dofahee (kalk) - wordt veel moeite en arbeid besteed; bijna elke familie heeft haar eigenaardig model en tracht dit door het aanbrengen ran fijn en kunstig vlechtwerk, in de pandanreepen uitgesneden arabesken, kleurschakeeringen, bont papier, mica, die daartoe van de Soela eil. en Tomboekoe wordt aangevoerd, parelmoer enz. boven dat van haar buurman te doen uitmunten; namaak is dan ook hierbij volgens 's lands adat verboden en wordt zulk een patentdiefstal gestraft met verbeurdverklaring en boete.

In de meeste huizen der Alfoeren, vooral echter bij de Toebarezen vindt men onder het dak en aan de wanden allerlei schedels, graten, vinnen, enz. hangen, afkomstig van op jacht of bij de visscherij buitgemaakte dieren; ook de in den omtrek van het huis staande boomen zijn dikwijls met een fraaie collectie bekkeneelen van varkens en herten behangen. De verlichting heeft plaats met harsfakkels, die men meestal in zoogenaamde salo-ma-djonitri of standers plaatst (fig. 29).

Intusschen zijn de Alfoeren groote liefhebbers van glas- en aardewerk, dat echter nog wel eens met den eigenaar begraven wordt; vooral op oud porcelein zijn zij zeer verzot; de reiziger staat dan ook verbaasd soms midden in de wildernis ouderwetsch porcelein en kostbaar glas- en kristalwerk te vinden; vooral in Sahoe en Galella is dit het geval en bezit de bevolking daar tal van groote kostbare borden, karaffen, compôtes, saus-kommetjes, enz., die zij of in vroeger tijden geroofd, dan wel voor buitensporig hooge prijzen heeft gekocht.

De levenswijze der Alfoeren is zeer eenvoudig.

Sago, hier hoeda geheeten, is overal het hoofdvoedsel; dit wordt in den regel genoten als brij en draagt dan den naam van "papéda", waarbij men gebruik maakt van twee stokjes, om de slijmerige massa te snijdeu, in de saus, meestal bestaande uit azijn (zure sagoeer) met spaansche peper (Lombok setan) rond te wentelen en naar den mond te voeren; ook eet men de sago in den vorm van langwerpig vierkante koeken of brooden, "lempee" genaamd, waartoe het geschifte en drooge sagomeel in een heet gemaakten aarden vorm, "forno" of "raroe" genaamd, gestrooid wordt, en met een pisangblad bedekt daarin gaar wordt; de derde manier, om sago gereed te maken, is het, bij gebrek aan een vorm, in een jongen bamboe doen en roosteren van het meel, welke spijze "hoeda-bokko-bokko" genoemd wordt; de vierde wijze van bereiding bestaat uit het in Downloaded from Brill.com04/26/2023 02:58:58PM 
wokka-bladeren wikkelen en roosteren van het sagomeel, hetgeen men dan "kassido" noemt.

Na de sago bekleden de wastella of Turksche tarwe en do "kooin of pisang de eerste plats; zij worden meestal half rijp geroosterd of in ' $t$ vuur gepoft als ontbijt gegeten.

Maar ook aardvruehten, zooals *imas (batata), "kihan (oebi), "kladien, "katella", enz. worden bijna overal ten eigen behoeve verbouwd.

Rijst is voor den Alfoer altijd meer een versnapering en wordt in den regel slechts bij feestelijke gelegenheden en bij wijze van fijn onthaal gegeten.

Behalve de in de bosschen gevonden goloba, en andere wortelen, aren-, klappa- en wolka-palmiet, nangka- en andere boouvruchten, gebruikt de Alfoer ook zekere boomblaren als toespijze, zooals b.v. het blad van den genemoeboom, dat van den "papaya", enz., terwijl de bossee-, de gagoe-, de boötta-, de liliping- en de djaloc-djaloe-planten, benevens bayam, zijne groenten uitmaken.

De vruchten van de in het wild groeiende ananassen, langsap, en djamboe-boomen leveren benevens tal van wilde bessen, enz. het dessert.

Alle spijzen worden meestal zonder zout gekookt en zijn dus erg flauw, weshalve de Alfoer zich onder het eten bedient van een stukje klipzout, waarvan hij het noodige afschrapt.

Het dierlijk voedsel bestaat uit bijna alle schelp- en schaaldieren, diẹ de Alfoer maar machtig kan worden; zekere soort bok-, sago- en neushoorn-torren, allerhande visschen, palmiet en rottanwormen (kevermasker), zwarte kikkers, schildpaddeu, zeker soort legoeanen, koesoe's, eekhoorntjes, allerlei gevogelte, krokodillen, eieren van vogels en schildpadden, herten, zwijnen, enz., kortom bijna alles wat maar eenigszins eetbaar is en op zijne zwerftochten in bosschen en op zee door hem gevonden wordt; er bestaat echter ook daarin veel verscheidenheid; de eene Alfoer is vies van hetgeen de ander met smaak eet; kaaimansvleesch b. v. wordt slechts door enkelen gegeten, terwijl anderen weder geen paling nuttigen, enz.

De volksdrank is het gegiste sap, verkregen uit aren- en inder palmsoorten, hetwelk meestal in vrij zuren staat soms eenige dagen oud en bijna in azijn overgegaan met den meesten smaak genuttigd wordt. Deze drank wordt dan ter onderscheiding ran het versche en een paar uren oude sap, die 
"sagoeweroe manis" heet, "sagoeweroe fotoeroe" genoemd en heeft volgens hun zeggen in tegenstelling van den voor den buik nadeeligen verschen sagoeëer astringeerende en heilzame eigenschappen.

Onmatigheid in het gebruik van dezen drank is vrij wel aan de orde van den dag, maar ook van arak en jenever houden mamnen en vrouwen evenveel.

\section{III.}

De tjidakko. - De gado of baro. - De tolloe. - De mokkoe-ma-dodaai. Hoofdversiersels. - Halssnoeren. - Armringen en banden. - Beenringen en banden. - Het zwartmaken der tanden. - Het kleuren der nagels. Het tatoeeeren. - Het scheren der beenen.

\section{(Platen III en IV.)}

De nationale kleeding der Alfoeren is voor de mannen de "tjidakko" en voor de vrouwen de "gado."

De tjidakko of piesa (fig. 1) is een \pm 4 meter lang en \pm 0.5 meter breed stuk geprepareerde boombast of schors, dat, door de beenen gehaald, eenige malen om de heupen wordt gewonden, waarbij de ontplooide uiteinden voor en achter komen te hangen en dienen om de schaamdeelen geheel te bedekken.

De gewone of dagelijksche tjidakko's hebben de natuurlijke kleur en zijn naarmate de boomsoort waarvan zij afkomstig zijn, geheel wit, geel bruin of rood bruin.

Door het verwen en het aanbrengen van met plantensap gekleurde teekeningen, meestal arabesken en lijsten, het maken van franjes of kwastjes en het opnaaien van mica, parelmoerplaatjes aan het voor- en achtereinde wordt de gewone tjidakko tọt een feestgewaad gemaakt.

De patronen, zonder hulpmiddel door de vrouwen ontwerpen en gekleurd, zijn vaak niet onverdienstelijk en verraden dikwerf goeden smaak; wanneer de teekeningen op den voorkant van den tjidakko als het ware voorzien zijn van vierkante lijsten (zie de teekening), dan beteekent elk raam of elke lijst een verslagen s jand.

De gado of baro (sarong) (fig. 2), van dezelfde stof als de tjidakko vervaardigd, heeft eene lengte van $\pm 1.5 \mathrm{M}$. en een 
breedte van \pm 0.75 ; zij wordt gedragen als een kain of doek, en wel zoo, dat althans een der uiteinden op de heupen valt om te voorkomen, dat de vaak niet zeer soepele stof de vrije beweging der beenen belemmert; zulk een kleedingstuk kan bij wijlen zeer onvoegzaam zijn, vooral bij het zitten; het wordt even als de tjidakko soms beschilderd en versierd.

Het bovenlijf blijft meestal bloot; vooral is dit het geval bij de jonge lieden van beiderlei kunne; toch worden ook door hen evenals door de getrouwden en meer bejaarden jakken of baadjes van boombast, "kottanga" genaamd, gedragen (fig. 3).

Ook deze baadjes, met of zonder mouwen, worden behalve bij den veldarbeid ook bij feestelijke gelegenheden gedragen, nadat men ze door het aanbrengen van franjes, mica, borduursel en gekleurde arabesken verfraaid heeft.

Deze oorspronkelijke kleeding is tegenwoordig echter bijna geheel verdrongen door katoenen sarongs, baadjes en broeken.

De mannen dragen verder algemeen een hoofddoek, "lenso", en een "tolloe" (fig. 4) of hoed van pandanblaren, welke hoeden, hoewel in vorm, een kegel met uiterst flauwe helling, bijna allen gelijk, echter in kleur, versierselen en wijze van uitvoering zeer verschillend zijn, daar hier even als bij zoo veel andere zaken elke groote familie "misketti" haar eigen model heeft.

Vooral Galellarezen en Tobellorezen maken veel werk van deze hoeden, die zij veelal met teekeningen van heel kleine schulpen, "tigo" genaamd, versieren.

Bij de hoerlen der hoofden wordt deze kegelvorm veelal gekroond door een soort torentje, aan welks top zich dan een kwast of een bosje kapok bevindt. Figuur 5 is de hoed van een Sengadji.

De hoeden, door de Islamsche Alfoeren in het Wedasche en Mabasche vervaardigd van allerlei grootte en gedaante, zijn echter in hun soort de mooiste en genieten eene niet onverdiende vermaardheid.

Evenals alle onbeschaafde volkeren schept de Alfoer er een bijzonder behagen in, om zich van tijd tot tijd eens op zijn Europeesch uit te dosschen; oude uniformen, civiele en militaire steken, hoeden, epauletten enz. vinden dan ook op Halemahera gereeden aftrek, maar ook bonte Turksche vesten, zijden en fluweelen kaftan's, scharlaken baadjes, enz., meer of minder met veelal valsch goud- of zilver-passement afgezet, zijn zeer gezochte artikelen en maken den bezitter tot een der gelukkigste en ijdelste stervelingen. 
Op deze kleeding is men dan ook uiterst zuinig en slechts bij buitengewone gelegenheden wordt zij voor den dag gehaald; de zuinigheid op kleeding strekt zich ook uit op de meer ordinaire en dagelijksche kleeding, die bij de mannen in een hoofddoek, een tjidakko en een opgeschorte sarong en bij de vrouwen uit een sarong, benevens een meestal net de mouwen als een boezelaar om den hals gedragen katoenen baadje van roode of blauwe kleur bestaat; elk Alfoer ontdoet zich dan ook bij regen van alle maar eenigszins te ontberen kleedingstukken, welke hij in zijne hem meest vergezellende kokoya of onder zijn tolloe bergt, om ze voor nat te bewaren.

Galellarezen en Tobellorezen gebruiken veelal in stede van den tjidakko korte katoenen broeken van het fatsoen onzer zwembroeken, "tjelana popo" genaand, maar ook lange broeken en baadjes zijn bij hen meer in zwang dan dit elders, het district Sahoe uitgezonderd, het geval is.

De Sahoerezen zijn in hum dagelijksch kostuum voor het meerendeel kenbaar aan hun half rood en half geel gekleurden hoofddoek en den door de meesten gedragen katoenen tjidakko, waartoe zij de lange tulbanddoeken der Arabieren gebruiken. Hoewel de door de mannelijke Alfoeren gedragen openstaande katoenen baadjes of kabaya's in het algemeen lang van snit zijn en tot de knieën reiken, worden die der hoofden, die meest allen kleeren dragen ', liefst nog iets langer gemaakt; de meesten dragen als teeken van hunne waardigheid een stok, "tarakan" of een rottan. Fig. 5 (b) is de tarakan van een Sengadji, fig. 5 (c) de rottan van een hoofd.

Ook de zakvormige baadjes der vrouwen — want schier allen zijn in het bezit van sarong en baadje - reiken vaak tot aan de knieën.

De sarong wordt in den regel door de vrouwen niet op Maleische wijze als een rok, maar bij wijze van een doek of kain en dan nog wel ter halver breedte opgevouwen om de heupen geslagen, gedragen; hij reikt dan ook op deze wijze gebruikt meestal slechts tot aan de knieën en staat aan den linkerkant min of meer open; bij de mannen doet deze eigentlijk meer als mantel en sprei dienst dan wel als sarong.

Om het midden dragen de mannen en ook de jonge meisjes een band, hetzij van gevlochten rottan of pandan, hetzij van

1 Mahiroos, dorpsoudsten, en kapitta's, "oorlogshoofden", taitgezonderd. 
herteleer, dan wel iets dergelijks vervaardigd (fig. 6), waarmede zij zich uiterst sterk rijgen, "boedee", daar een dun middel algemeen voor schoon gehouden wordt.

Onafscheidelijk en onontbeerlijk zijn roor den werkelijken Alfoer twee voorwerpen, die men deswege onder zijn kostuum rangschikken moet; in de eerste plaats de "peda" (fig. 7), een soort houwer of kapmes, in de landstaal schertsende "de Alfoersche zakdoek" genaamd, en ten tweede de mokkoe-madoodaai (fig. 8), zijnde een bergplaats van de benoodigdheden voor het sirih-kauwen, tevens reis-necessaire, die in sommige streken (Toebaroe, Kau, enz.) in een hangtaschje, "kadoe" (a) geheeten, over den schouder gedragen, op andere plaatsen echter (zooals te Galella, Tobello, Loloda) in eene kabila (b) of een soort handkoffer van rottan, "tagalaya" (c), onder den arm of achter in den sarong gewikkeld, overal medegevoerd wordt.

In zulk een kadoe, meestal uit herteleer, maar ook wel uit koord of zeildoek en genemoedraad vervaardigd en vaak met franjes, knoopjes en koperen plaatjes versierd, vindt men even als in zulk een kabila bijna altijd de volgende voorwerpen:

10. een dorro of kleine doppo-doppo, (fig. 9), een soort broodmes met of zonder houten scheede, dienende tot knutselarijen, het villen van dieren, enz.

20. een stuk ijzer, "koeti", in den vorm van een deurkruk dan wel een oude sleutel om te boksen (fig. 10).

30. een "dettoe-dettoe" of vuursteen en vuurslag (fig. 11); men slaat echter ook met behulp van een porceleinen scherf het vuur uit een stuk bamboe, waartegen nen den goed gedroogden baroe (zwamachtig aangroeisel, dienende tot het stoppen der prauwen) van den goemoetoe-boom vermengd met half verkoolde plantaardige vezels houdt.

40. een "boekka", zijnde een net bewerkt bamboesje of noot met ongebluschte kalk (fig. 12).

$5^{\text {r. }}$ eenige losse sirihvruchten en pinangnoten (fig. 13).

60. een doppo-ko, zijnde een houten plaatje met zeven gaten, dienende, om met behulp ran het daaraan vastgebonden open netje den dag der week aan te wijzen (fig. 14).

70. een stukje spiegel voor het toilet.

So. een haartangetje (fig. 1.5a) en een bamboevork voor het kammen (fig. 15b);

ten slotte bij jagers den kruidhoorn (fig. 16) enz. en den nallinalli, een gevlochten bal met kokosvezels gevuld (fig. 17). 
Bij sommige stammen Galella, Loloda, Tobello, wordt echter het doppo doppo of mesje aan den boedee of buikband gedragen.

De nationale versierselen der Alfoeren zijn in de eerste plaats de ngarra ngarra (fig. 18), een soort van zegekrans, in vele streken door de uit den strijd terugkeerende krijgers gedragen, $\pm 1.2 \mathrm{M}$. lang en vervaardigd van gekerfde boombast; hij wordt om het hoofd gewonden en wel zoo, dat een der uiteinden naar voren uitsteekt en de andere op den rug hangt; de aan de uiteinden afhangende ronde schịfjes geven het getal der verslagenen aan. Hierbij worden tevens gedragen twee soppoe's of sop's (fig. 19), een soort van vederbossen van kakatoeavederen, die schuins van achter de ooren als twee horens aan weerszijden naar voren uitsteken.

Het gewone versiersel van mannen en vrouwen is de vaak uit schoone houtsoorten vervaardigde kam of woessi (fig. 20), die soms door het inleggen van parelmoer, soms door sierlijk snijwerk en het aanbrengen van verschillende kleuren verfraaid wordt; zij dient bijna uitsluitend als sieraad, want het lang gedragen haar wordt gekamd met lange drie- à vijfpuntige vorken van bamboe en de bekende kleine Chineesche kammen.

Door beide seksen wordt de "woessi" voor den op het achterhoofd gelegden haarwrong, "goetto", gedragen; bij feesten steekt men er kruiselings een paar haarpennen, "leroe" (fig. 21), achter, vervaardigd van een sierlijk met bont gekleurde pandanreepen omwikkeld houtje, waaraan kwasten van fijn gesneden kiha-bladeren, enz. afhangen; meestal hebben zij de gedaante van een Janitzaren carillon, of wel van een langwerpige maleische vlag.

De jonge meisjes dragen daarbij eenige bloemen in het haar; ook steken ze deze even als de jonge lieden achter de ooren; deze bloemen zijn eenige gele en roode vossenstaarten of wel de kambodja-bloem of de kembang sepatoe.

Om den haargroei te bevorderen, dragen de jongelieden een ronde doorboorde houten schijf, "ta-dauroe genaamd (fig. 22), wordende het haar door het gat gestroken, over den bovenkant der schijf uitgespreid en aan den benedenkant stijf vast gebonden, zoodat het haar door de zwaarte van het hout gerekt wordt.

De ruw bewerkte zilveren of koperen oorringen, "koemetta" (fig. ..3), worden dikwijls rervangen door de krom gebogen en gedroogde teenen van den kohebba of gier (fig. 24), of 
wel door de in elkaar geschoven lange nagels ran de moleo of boschkip (fig. 25), en den koessoe; ook bosjes van bonte veeren of welriekend hout (fig. 26), kwasten van de kiha-bladeren (fig. 27), "leroe" genaamd, enz. treden wel eens daarvoor in de plaats.

Om den hals wordt door allen meestal een goe-oel-lee (fig. 28), zijnde een snoer met kralen, waaraan vaak eenige oude muntstukken hangen, gedragen; soms bestaan deze halskettingen slechts uit een koordje, waaraan eenige krokodillenof varkenstanden, dan wel de borst ran den boerong epaulet (Semioptera Wallacei) enz., soms zelfs een varkensstaartje bevestigd zijn.

Door de mannen worden om den bovenarm smalle en breede armbanden, "aro-aro", gedragen van gevlochten en gekleurde pandanrepen of rottan vervaardigd, welke banden buitendien veelal met figuren van schulpen, enz. bezet worden en dan heel aardig uitzien (fig. 29). Bij feesten steekt men ook daar overal bloemen tusschen.

Om den pols worden door mannen en vrouwen een of meer witte armringen (fig. 30), "patjeda" genaamd, vervaardigd van een conus-schulp; bij de vrouwen klimt het getal dezer soms met graveeringen versierde armringen, wel eens tot zes, waardoor dan elke beweging met een eigenaardig gerinkel gepaard gaat. Ook uit één stuk vervaardigde zwarte houten ringen, "basanee" genaand (fig. 31), akar-bahar takken, smalle reepen van de overal op Halemahera gevonden, rood en witgestreepte Trochus-schelp, "bia soessoe (fig. 32), worden evenals rond en plat geslagen koperdraad als armring gebruikt (fig. 33). Ook om de enkels worden door beiderlei kunne gevlochtene, en meestal zwart gekleurde voetbanden, "golongi" genaamd, gedragen (fig. 34); dikwijls zijn deze echter ook door zware voetringen van koper of zilver "talanga" vervangen (fig. 35).

Ook vingerringen draagt de Alfoer gaarne, en hoe grooter en meer in het oogvallend deze zijn, des te mooier; hịj draagt ze niet slechts van schulpen, van kralen, van schildpad, ran v ruchtpitten, enz., maar ook van koper en zilver, dikwijls voorzien van groote stukken gekleurd glas, soms zelfs met een daarop gesoldeerden halven gulden (fig. 36).

De tanden, die men als teeken der huwbaarheid afvijlt, worden zwart geverfd met een soort van ijzer-zwartsel, verkregen door een met djeroek en klappa bestreken houwer 
boven een met brandende houtskool gevulden klapperdop te doen aanloopen. De nagels, die op den duim na kort gehouden worden, kleurt men rosé met een mengsel van zakka- of giabebeblaren en lemmetjes met zout. Soeleppespelers (Alfoersche mandoline) laten ook den nagel van den kleinen vinger der rechterhand lang groeien.

Het tatoeeeren is bij hen een onbekende zaak; slechts in het Kausche maken de jongelieden zich wel eens met het sap van zekere plant eenige figuren op de huid, welke teekens echter na korten tijd verdwijnen; ook bij den "tjakalellee", krijgsdans, smeren de dansers zich eenige kalkstrepen op het gelaat, om zich een woester voorkomen te geven; verder wordt door eenige stammen "Tobello", "Toebaroe", enz. door de mannen vrij algemeen het haar aan de beenen gedeeltelijk weggeschoren en wel zoo, dat er om het been twee vingers breede, zeer in het oog vallende haarkringen worden gevormd, welke bewerking "moemoessee" of "boborotto" genaamd wordt.

Het haar op het gelaat wordt op den knevel na meestal uitgetrokken; slechts enkelen dragen een vollen baard, velen daarentegen een ringbaard.

\section{IV.}

Wapens. - Oorlogshoofden. - Voorbereiding tot den oorlog. - Wijze van
oorlog. - Wapenhandel. - Ceremoniën bij den terugkeer nit den strijd. (Plaat V.)

De oorspronkelijke wapens, waarvan de Alfoer zich bedient, zijn de "djoebi-ma-hera" of boog, de "sagoe-sagoe" of lans en de klewang, naar de soort "rinom" of "go-ollee toboekkoe" geheeten.

De boog (fig. 20 en 21 ), waarvan lengte in de verschillende streken varieert tusschen een en twee meter, wordt vervaardigd uit het hout vau den wokka-palm en heeft als koord den met damınar ingesmeerden en tot een touw gedraiiden bast van den genemoe-boom.

Hei min of meer platte booghout heeft aan het einde waar het eenigszins spits toeloopt, een kerf, warmede de aan die 
zijde niet vastgebonden, maar met een lus voorziene koord correspondeert.

Om den boog, die, als hị niet gebruikt wordt, altijd ontspannen is, te spannen, plaatst men het breede einde tegen de binnenzijde van den linkervoet en vat het andere met een kerf voorziene boveneinde met de linkerhand, alsdan drukt men met de linkerknie tegen den boog totdat het bij de daardoor ontstane kromming mogelijk wordt, het koord in de kerf te schuiven; waarna de boog gespannen is.

De vrịj ruw bewerkte uit riet, "lola", vervaardigde pịlen, "djoebi ma saai" genaamd, zijn naar de verschillende daarop aangebrachte pijlpunten onderscheiden in vogel-, wild- of vischen oorlogs-pijlen.

De vogelpijlen, voor kleinere vogels althans, zooals duiven, papegaaien enz., bestaan uit drie lange smalle, spits toeloopende en met weerhaken voorziene bamboezeli, welke in den vorm van een gelijkzijdigen driehoek in den pijl gestoken en ter halver lengte door een bandje bij elkaar gehouden worden (fig. 13). Voor grootere vogels maakt men gebruik van een pijl met grooten in dolkvorm gesneden bamboe-punt (fig. $\tau$ ) of wel gemonteerd met een van weerhaken voorzien en scherp. aangepunt stuk wokka of arenhout, met welke laatstgenoemde soort men ook op klein wild schiet (fig. 9 en 7).

Voor de jacht op groot wild en in den oorlog gebruikt men zwaardere soorten (fig. 11) of wel pijlpunten, vervaardigd uit oude messen (fig. 12) of ook uit het geduchte boven den staart gelegen wapen van den Tkan njoa, een bontgevlakte roggesoort (fig. 15). Deze vrij lange en aan weerszijden met een rei weerhaken voorziene doorn wordt daarbij vaak nog met het gift van dien visch bestreken en veroorzakt dan even gevaarlijke als niterst pijnlijke wonden.

Het gebruik van vuurwapens, vooral vuursteengeweren, heeft evenwel het boogschieten op vele platsen grootendeels vervangen; echter zullen bij de zeer verstandige belemmering, die de invoer en handel in buskruit en vuurwapens in deze streken ondervindt, pijl en boog weldra weder in veler handen zijn.

Thans zijn het vooral de Toebarezen en de Kausche stammen "Toegoetil" en "Madollee", die de meeste bedrevenheid in het hanteeren van den boog bezitten; zij schieten daarmede vrij nauwkeurig en weten b. v. tot op \pm 80 passen tamelijk kleine en smalle voorwerpen, zooals een geleding bamboe, tali, te raken. 
Bij het schieten gaat de boogschutter bijna geheel uit de rechterflank staan, vat den boog met de linkerhand ter halver hoogte en legt den pijl in een door den voorsten inger dier hand gevormd schietgat; de koord wordt gespannen door het achteruit trekken van den op de koord gezetten pijl met den duim en voorsten vinger der rechterhand, hetgeen eenige kracht en oefening vereischt.

Het geliefdkoosde wapen van den Alfoer is echter de lans, waarmede hij tot op meer dan zeventig pas een klapper (cocosnoot) weet te treffen. Hij heeft ze van allerlei afinetingen en gedaante; velen zijn als buit uit andere landen meegebracht en van vader op zoon overgegaan.

Er zijn echter vier bepaald inheemsche typen en wel:

$1^{0}$. de tittiala (fig. 10), een vrij korte slechts $\pm 1.5 \mathrm{M}$. lange lans, bestaande uit een steel van buigzaam hout voorzien van een ijzeren harpoen-punt; soms heeft deze soort echter in stede van een ijzeren slechts een met rottan bevestigden bamboezen punt (fig. 14).

20. de garagagdji (fig. 6), een langere uit wokkahout vervaardigde lans met tal van weerhaken, die echter de lengte van \pm 2 meter niet te boven gaat.

$3^{\circ}$. de toei, (fig. 18), een iets langere scherp aangepunte dunne bamboe, en

$4^{0}$. de sago-sago sioekompottee (fig. 16), een lange zware lans, vervaardigd van een sioekompottee-stam (wilde pinangsoort), soms opgevuld met zand om de kracht van den stoot te verbeteren.

No. 2 dient uitsluitend roor de hertenjacht, no. 1 en 3 worden èn voor varkens èn voor herten gebezigd, terwijl de laatste soort slechts voor de drijfjacht op varkens bestemd is; in tijd van oorlog worden alle soorten, ook de poesaka's gebruikt.

De klewangs, die men bij de $\Lambda$ lfoeren ziet, zijn om dezelfde reden als de lansen nog al uiteenloopend van vorm en grootte, maar ook hierbị heeft men twee soorten, die door hun vorm, menigte en ouderdom als de nationale dienen te worden beschouwd.

Vooral is dit met de $1^{\mathrm{e}}$ soort, den rinom (fig. 23) het geval, welk wapen veel gelijkt op een groot scheermes, dat met een bijna onder $120^{\circ}$ staanden sinallen en dikken steel geplaatst is in een houten, soms sierlijk bewerkten greep, die 
aan den binnenkant een soort van stootplaat tot handdekking en aan het boveneinde een rond houten bolletje tot versiering heeft, in welk bolletje de haarbossen der verslagen rijanden bevestigd worden; deze houwer, waarin een zoo zware siag zit, dat men daarmede in eens een hoofd kan afkappen, wordt wel eens in een bamboe over den schouder hangende gedragen.

De tweede soort, de go-ollee toboekkoe (fig. 22) heeft de gedaante van een langbeenigen driehoek van $150^{\circ}$ met kleine basis, waarvan de top in den greep ligt, welke greep bijna denzelfden vorm heeft als die der eerste soort, met vitzondering dat zich in stede van het bolletje een verlengstukje aan het boveneinde bevindt, waarin de haarbosjes geplaatst worden.

Het mes, "doppo-doppo", ook "dari" en "itakero" geheeten, dat vele Alfoeren dragen, dient slechts tot meer vreedzame doeleinden, daar de Alfoer in de hanteering van een mes als wapen zoo goed als onbedreven is.

Tot dekking van zijn lichaam gebruikt de Alfoer een van een lichte houtsoort vervaardigd schild of beukelaar, "salawakko" genaamd. Deze uit één stuk vervaardigde schilden verschillen sterk wat grootte en bewerking betreft, hoewel de grondvorm "een naar binnen gebogen langwerpig met een greep van achteren in het midden", bij allen dezelfde is; deze schilden worden verdeeld in vier soorten:

10. de roggo-roggo (fig. 1), het groote schild, heeft bij een lengte van ruim een meter, een breedte van bijna vijf decimeters en een dikte van drie à vier centimeters, slechts een zeer geringe buiging, zoowel boven- en benedenwaarts als naar den handgreep toe.

In het midden waar alle soorten nauwer worden, bevindt zich een "maliboekkoe" of navel die boven het zwartgekleurde oppervlak dat met eenige rijen haarlokken van vijanden en eenige kalkstreepen of stippen, die het aantal verslagenen aangeven, versierd is, uitstrekt. Ook langs den rand is vaak een ornament van menschenhand aangebracht.

De tweede soort, de salawakko toboekkoe (fig. 4), lang en smal van vorm, heeft een sterke buiging, zoowel boven- en benedenwaarts als ook naar het midden van den achterkant waarin zich de greep bevindt.

De zwart gekleurde en over de lengte in vier stomp aan elkaar sluitende, soms echter ook door ribben gescheiden vlakken

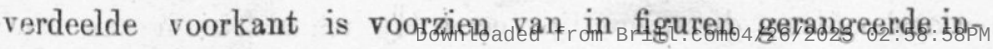


gelegde' stukjes parelmoer of witte schulpen (ovula). Dikwijls gaat om den rand van het schild een lijst van rottan.

De zwarte kleurstof roor alle soorten van schilden levert de inktvisch.

De $3^{\mathrm{e}}$ soort, het gewone schild, is slechts 70 decimeter hoog en eenigszins breeder en dikker dan het lange (fig. 2); ook hebben de vier v]akken meestal scherpere grenzen, terwijl de figuren schaarscher geplaatst, dikwịls soms slechts in het midden, of wel in het midden en aan den boven- en benedenkant voorkomen en meer uitsluitend ran schulpen en porcelein-scherven vervaardigd zijn. Vindt men in het midden van het schild vier der groote witte schulpen, "lolekko" genaamd, dan toont dit aan, dat de bezitter een man van grooten moed is, en noemt men een dergelijk schild lakko raha (vieroog); dar men echter het in het schild voeren van rier schelpen niet door certificaten behoeft te staven, treft men nog al reel ran dergelijke schilden aan.

Bevinden zich op een schild meer dan vier groote lolekko's en zijn de rakken door ribben gescheiden, dan noemt men dit een salawakko maponna (fig. 3).

De 4e soort, het kleine schild, salawakko ngoffa of salawakko kapitta genaamd, dat in den regel nog geen halven meter lang is, wordt door de voorvechters en kapitta's gebruikt en geeft èn door de vier schulpen in het midden èn door de geringe afmetingen duidelijk te kennen, dat de eigenaar een man vau buitengewonen moed en groote bedrevenheid in het hanteeren der wapens is.

Over het algemeen hebben deze schilden echter als dekkingsmiddel een uiterst geringe waarde; tegen een geweerkogel is deze gelijk nul te stellen en geeft de Alfoer dan ook in tijd van oorlog liever aan den eersten besten dikken boon de voorkeur.

Vele Alfoeren zijn in het bezit van vuurwapens, zoowel vuursteen- als percussie-geweren, waarmede zij, daar zij een scherp oog en een raste hand bezitten, den deerniswaardigen toestand, waarin zich verreweg de meerderheid dier wapens bevindt, in aanmerking genomen, werkelijk zeer goede resultaten weten te verkrijgen en zelden hun doel missen; hierbij mag echter niet vergeten worden, dat zij, daar zij het wild meestal bekruipen, hoofdzakelijk slechts op korte afstandeu schieten.

De Alfoeren bezitten behalve hun gewone hoofden ook zekere oorlogshoofden, die eigentlijk eerst bij het uitbreken van een 
oorlog in functie treden en hun aanzien in tijd van vrede slechts aan hun vroeger verkregen lauweren te danken hebben; deze hoofden voeren den titel van "kapitta."

Behalve deze kapitta's hebben sommige stammen of negorijen b. v. Toebaroe, Kajoa, enz. nog een afzonderlijk opperoorlogshoofd, die, elders vertoevende, bij het begin van den krijg ter plaatse verschijnt en van het strand zijne boodschappen landwaarts stuurt, om de strijders op to roepen; zulke hoofden noemt men sadaha's.

De bevolking der binnenlanden moet zich, zoodra hij verschijnt, onverwijld naar het strand begeven en elke familie of "misketti" (groot huishouden) één weerbaren man leveren, die alsdan in de door de strandnegorijen te leveren korra-korra's ten strijde trekken.

Als er in Kau strijders voor den een of anderen hongi (krijgstocht) moeten worden opgeroepen, dan wordt er (zie daarover ook Buddingh's reis op Halemahera) door de oorlogshoofden, of door de zendelingen van den Sultan een feest in de negorij gegeven, en wordt, nadat de bijeengeroepen bevolking goed gegeten en gedronken heeft en de geestdrift ten top gestegen is, den mannen afgevraagd wie er mede ten strijde wil trekken; degene die dan eens ja gezegd heeft, durft later uit schaamte niet terug te trekken.

Als de tijd om op te rukken gekomen is, begeven zich de aanstaande krijgslieden onder leiding van een bekwaam gomma hattee (toovenaar) naar het bosch op een der vele plaatsen, waar men weet dat zich een machtige geest ophoudt; veelal is dit een hooge boom, waartegen men dan ook de medegebrachte paloedie (draagmand) plaatst. Hierop wordt door den toovenaar de geest opgeroepen en verzocht in den draagmand te gaan zitten; zoodra alsdan de gomma hattee onder allerlei kunsten kennis geeft dat dit geschied is, gaat de troep hoogst verblijd huiswaarts al schreeuwende "wongi ino! sonnee hiera!" hetgeen beteekent: "de geest is met ons, niemand zal sterven." Evenals bij vele inlandsche volken gelooft vooral de in de bossohen vertoevende Alfoer namelijk dat verre reizen den dood tengevolge hebben.

De draagmand wordt nu in afwachting van het vertrek in de kokkiroba (geestenhuis) opgehangen en den geest een feest aangeboden. Daarna trekt men ten strijde, waarbij de paloedie als palladium dient. 
$\mathrm{Na}$ afloop van den hongi geeft men den geest, als deze zich goed gehouden heeft, drie dagen nà de terugkomst wederom een feest, waarop hij in den feestelijk uitgedoschten paloedie naar zijue vorige plaats teruggebracht, in vrijheid gesteld en voor de bewezen diensten bedankt wordt, waarbij men hem tevens de belofte afneemt, om een volgende maal nog eens te helpen.

Op andere plaatsen, Galella, Tobello, enz. is meestal een bloote kennisgave der hoofden, dat een hongitocht gehouden zal worden voldoende, om talrijke liefhebbers te verkrijgen; desniettegenstaande heeft echter ook hier elke stam of negorij de bepaalde verplichting een door den adat vastgesteld aantal strijders op te brengen; meestal wordt dit getal altijd aanmerkelijk overschreden en zoude men daaruit tot een zeer oorlogszuchtig karakter der bevolking kunnen besluiten ; men moet echter daarbij, hoewel strijdlust en zucht tot avonturen zeer zeker hoofdredenen zijn, ook met hun hebzucht en winstbejag rekening houden.

Bij een aanval moeten volgens 's lands adat de kapitta's en mahimo's (dorpsoudsten) het voorbeeld geven en vóór de anderen uitgaan; een rechtstreeksche aanval wordt echter niet ondernomen, als er maar eenigszins kans bestaat het doel door een overval te bereiken. Het op den loer liggen en een geheel weerloos zijnden vijand onverhoeds overvallen en afmaken wordt evenals bij de meeste, zoo niet al de inlandsche volken bepaald voor een heldenfeit gehouden.

De gave van beloeren en bespieden van de gekozen slachtoffers bezitten vooral de Tobellorezen in hooge mate, die als zeeroovers geleerd hebben hun doel, hetzij dorpen of vestigingen hetzij prauwen dau wel de groote Padoeakan's der Mandarezen, soms dagen achtereen te bespioneeren, om eerst dan, als zij weten dat de bevolking zorgeloos is of de bemanning slaapt, hun kans waar te nemen.

De Halemaherasche Alfoeren hebben een bizonder krijgsgeschreeuw, daarin bestaande, dat de voorvechter, kapitta of ander hoofd een luidklinkend "A-oe!" (bloed) uitgalmt, waarop dan allen met een krachtig en langgerekt "i-jee " (drinken) invallen, welk geschreeuw werkelijk veel indruk maakt.

Hoewel het koppensnellen geen bepaalde landsinstelling is, zal geen Alfoer verzuimen zijn verslagen vijand, met welks haar hij zijne wapens versiert, het hoofd af te houwen en na zijn bloed gedronken te hebben, diens lichaam gruwelijk te verminken. 
Wamueer het echter voor een enkele maal te doen is, om een kop te snellen, makkt men gebruik van de volgende list om het slachtoffer buitenshuis te lokken; men werpt namelijk het een of ander tegen de deur en plaatst zich daarnaast, om, zoodra de bewoner naar buiten treedt, hem onverwachts een doodelijken houw in den hals te geven.

Een adat of bijgeloof, waarschijnlijk door overlevering ontstaan, ontraadt den Alfoer ten sterkste de "Companie" te bevechten, daar zulk een oorlog volgens de vertelling toch altijd hun nederlaag, zoo niet hun uitroeiing ten gevolge zal hebben, weshalve zij ook altijd de wijk naar hume bosschen zullen nemen in stede van bv. in bentings stand te houden; zij volgen daarmede echter een uitstekende taktiek, daar zij in de bosschen hunne goera's (tuinen) en schuilplaatsen hebben en volop voedsel vinden, terwijl onze zwaarbeladen soldaten zich onmogelijk met dezelfde snelheid langs de moeilijke, slechte en soms niet te herkennen voetpaden der wildernis kumnen bewegen als de bijna nakte en met het terrein vertrouwde Alfoer en schielijk gebrek aan het noodige moeten krijgen.

Hun versterkingskunst bepaalt zich geheel tot het aanleggen van verhakkingen en de kennis van eenige chicanes, zooals rantjoe's, blattoe's (springlansen), enz.

Als een voorbereiding tot den oorlog of oefening in het hanteeren der wapens is de tjakalellee of "krijgsdans" te beschouwen, waarbij veel behendigheid, vlugheid en kracht wordt ten toon gespreid, welke dans tevens een der meest gelief koosde volksvermaken is.

De terugkomst der krijgslieden, die hun aankomst door het blazen op tritonsschelpen en bamboezen kokers, welke ook voor krijgsklaroenen dienen, aankondigen en zich in sommige streken als symbool van den oorlog met jonge wokkabladeren tooien, gaat overal met feesten en plechtigheden gepaard, die behalve eenige grootere hieronder vermelde verschillen meestal op hetzelfde nederkomen.

Op Galella, enz. bv. worden de krijgslieden aan den ingang van het dorp ontvangen door de op het schoonst uitgedoschte jonge meisjes, welke hun den volgenden welkomstgroet brengen :

Saro saro!

Salama naro naro!

Pakkee togoe togoe!

No sidee naro naro!

Downloaded from Brill.com๑4/26/2023 02:58:58PM 
hetgeen zeer vrij vertaald beteekent: "ik ben verheugd (u terug te zien), gij moogt wel naar den oorlog gaan, maar moet zorg dragen terug te keeren en uit te rusten", waarna hun de handen en voeten gewasschen worden om als het ware het bloed af te spoelen.

Daarop biedt men hun in de Saboea (raadhuis) in een met bloemen versierden bamboe, "soppee", den welkomstdronk aan en wordt hun door andere jonge meisjes een geheele kip en een groote rijstkegel aangeboden, waarvan zij respectievelijk een stuk afscheuren en de spits af breken.

Voor gesneuvelde krijgers worden lijkfeesten gehouden en geestenhuizen gebouwd. Sommige stammen, zooals Galella, Loloda, Tobello, enz. brengen altijd de lijken of de beenderen der gesneuvelden naar de negorij terug; de daarbij tot vervoer gebruikte prauwen zijn reeds van verre te herkennen, daar zij tal van roode vlaggen en wimpels voeren.

Op Toebaroe, Kau, enz. dragen de Alfoeren in stede van wokkabladeren oorlogskransen van boombast, "langissa" genaamd, om het hoofd waarin twee als hoorns vooruitstekende vederbossen (saya's) zijn gestoken. Aan den ingang van het dorp worden zij opgewacht door de geheele bevolking. De Mahimo, vergezeld door een troep jonge meisjes en jonge lieden, die allen bamboezen drinkbekers dragen, treedt hun tegemoet en vraagt ieder op zijn beurt, hoeveel menschen hij gedood heeft, welk getal hij vervolgens in kerven uitzet op den bovenrand van den drinkbeker, die behalve met sagoeer gevuld is met kruiden, welke het vermogen bezitten den leugenaar te bestraffen.

De koker wordt daarop den krijgsman overhandigd, die hem leeg drinkt en in zijn huis of wel in de Saboea mag ophangen als eene herimmering aan zijne heldendaden.

Ook de schijfjes aan de uiteinden der oorlogskransen hangende geven het getal verslagenen aan.

$\mathrm{Na}$ deze plechtigheid gaan de mannen al tjakalleleënde en de vrouwen daar tusschen door dansende, "woetti woetti", naar de Saboea, waar het feestmaal gereed staat en de geheele kip en de spitse rijsthoop aangeboden wordt. 
Muziekinstrumenten. - De tiffa. - De arababoe. - De soeleppe. - De bangseli. - De tattaboea. - De papakka. - De Alfoersche zangen. De lolessa. - Het doppo-doppo. - Het rongo-rongo. - De djomma. De djorree-djorree. - De wella-wella.

\section{(Plaat VI.)}

Het geliefkoosde muziekinstrument der Alfoeren is de "tiffa" of Alfoersche handtrom, zijude meestal een stuk van een hollen arenstam aan eene zijde met een hertenvel overspannen; zij wordt echter ook wel van Jingoea-hout vervaardigd; het spannen geschiedt door onder den rottanband, waarmerle het vel vast zit, houten wiggetjes te drijven.

Men heeft tiffa's van allerlei soort, zoowel smal en lang als kort en dik en meer of minder net bewerkt, de lengte van drie kwart meter echter niet te boven gaande. $Z_{i j}$ worden bij feesten, enz. altijd en overal gebruikt.

De begeleiding van deze tiffa't geven de gewone inlandsche gongs (koperen bekkens), die van grootere en kleinere afmetingen min of meer den rijkdom van den bezitter bewijzen. Ook vindt men in vele dorpen groote ietwat heilige der negorij toebehoorende gongs, welke slechts bij plechtige gelegenheden geslagen mogen worden.

Het tweede instrument is de Alfoersche viool of "arababoe"; zij bestaat uit een klapperdop, waarover een hertenblaas gespannen is en waarin bij wijze van vioolhals een $\pm 0.5 \mathrm{M}$. lange dunne bamboe gestoken wordt; in dezen veelal net afgewerkten bamboe bevindt zich bovenaan een dwarshoutje, dat tot schroef, en beneden een houten meestal met snijwerk versierde, door den klapperdop in den bamboe geschoven stop, die als knop dient, bij het spannen van de enkele snaar van koperdraad, die door een lossen en lagen op den bovenrand der klapper geplaatsten kam van het vel verwijderd gehouden wordt.

Men bespeelt dit instrument met een strijkstok , "loei-loe'i" genaamd, vervaardigd van een gebogen bamboe waaraan bij wijze van paardenhaar goemoetoe-vezels gebonden zijn; deze zeer oorspronkelijke strijkstok wordt met dammar ingesmeerd. Het krijschende geluid is vooral op eenigen afstand niet ongelijk aan dat eener Chineesche klarinet of van een doedelzak. 
Het is min of meer een soloinstrument en de tiffa's dienen daarbij dan als begeleiding.

Dit instrument dient voornamelijk om bij de Djin-partijen de vijf bekende wijzen aan te geven, die noodig zijn tot het oproepen van den Djin (beschermgeest), zooals de Djin Wolanda, een danswijs, den Djin Tobello, een stukje waarop men tjakalelleën (krijgsdansen) kan, de Djin Hogga Hogga, een bedaard adagio, de Djin Boewaya, een weemoedig of beter gezegd treurig moderato en de Djin Gosoeng, de gewone wijs, een allegro.

Bij elk dezer wijzen kan het tiffa-accompagnement verschillend zijn; want ook daarbij onderscheidt men vijf soorten, die naar de daarbij aangegeven eigendommelijke maat, die met de toppen, de kneukels, de rlakke hand of een stokje geslagen wordt, in den Lossa-lossa, den Boettoe, den Baaikollee, den Babanari en den Toktokkoe worden onderscheiden.

Het derde merkwaardige instrument is de Alfoersche gitaar of "soeleppe". Zij bestaat uit een halven klapperdop op welks top een rechtstandig bamboesje een langwerpig dwarshout van geringe dikte, waarover de eenige snaar van koperdraad gespannen is, in horizontalen stand houdt; ook hier wordt de snaar door een dwarspennetje bij wijze van schroef en een stukje hout als kam, in gespannen staat gebracht.

De soeleppe is bij voorkeur het instrument der verliefden. Men zet het speeltuig met den klapperdop op de borst, gebruikt de linkerhand tot vingerzetting en tokkelt met de rechterhand, waarbij men in den regel den naam van het beminde voorwerp onder verschillende stembuigingen uitroept of eene geregelde serenade brengt, welk voorwerp niet ongevoelig voor een dergelijke attentie den verliefden "schäfer" in den regel niet lang laat wachten en met den pinang, het Alfoersche symbool der vriendschap, naar buiten komt. Wie zou dan ook ongevoelig kunnen zijn voor een liefdesklacht als de volgende:

Geki mooi ma ngoppa

Kikia koeda dotta Tjolle koeda dotta Geki mooi ma ngoppa Sininga ja soesoessa Awa kodo siolonna Geki ma ng'ngoppa Goeradji deo paramattı.
$O$ kind van zeker iemand

Waar zijt Gij gebleven (woord. nedergevallen)?

O Tjolle, waar zijt Gij gebleven ?

$\mathrm{O}$ kind van (zeker) iemand!

$\mathrm{O}$ wat lijd ik een smart

Heb toch medelijden met mij,

Gij kind van (zeker) iemand

(Zoo schoon als) goud en diamanten!

Downloaded from Brill.com04/26/2023 02:58:58PM 
Tjikaboe tjikaboe

Poella mokkoe tjikaboe

Poella bidoh tjikaboe

Poella dofahee tjikaboe

Poelia tabakko tjikaboe

Tabakko doedoe tjikaboe

Geki mooi ma ngoppa

To temo dede ugomma

$\mathrm{Na}$ kooija akoe de to wossa

Geki mooi ma ngoppa

Ma doedoe kanigogee.
Slechts een weinig, o zoo weinig,

Slechts een beetje pinang vraag ik,

Met een heel klein beetje sirih,

Ook een weinig kalk verzoek ik

Met tabak een heel klein beetje

En des noods een enkele roke.

O kind van (zeker) iemand,

Ik wilde zoo gaarne eens (vertrouwelijk) met u praten,

Zoude ik niet binnen mogen komen?

$\mathrm{O}$ kind van (zeker) iemand

Ik kan toch moeilijk (de heele nacht) buiteu blijven.

Men ziet de zaak is nog al duidelijk en de Alfoeren winden daar in den regel geen doeken om.

Des nachts kan men dit instrument zeer ver hooren.

De "bangseli" is een bamboezen fluit met vier gaatjes, die in den regel evenals de soeleppe slechts dient om serenades te brengen, waarbij de minnaar natuurlịk vrịj van het zingen is; het instrument wordt echter ook wel gebruikt bij het saleien (Djindansen) om in gezelschap van de arababoe den Djin op te vrolijken.

De "tattaboea" is een kinderinstrument, vervaardigd van een bamboe, waarin men een gat gemaakt en waarover men drie reepen van den bast met behulp van stukjes hout bij wijze van snaren gespannen heeft; bij het spelen tikt men telkens na het aanslaan van de hoofdsnaar twee malen op het houtje, dat het gat dekt.

Ook heeft men nog zeer groote tiffa's, "papakka" genaamd, die bij den tjakalellee of den salei geroerd worden met behulp van een stuk bamboe; ook de handtrommen worden bij den krijgsdans en den lego-lego op die wijze bespeeld.

De Alfoer is op zijn manier zeer muzikaal, dat wil zeggen: zeer dikwijls hoort men hem alléén luid zingen en gaarne geeft hij bij gezochte en ongezochte gelegenheden zijue deuntjes ten beste, die echter evenals de meeste inlandsche muziek niet zeer streelend voor Europeesche ooren zijn. Echter zit er over het algemeen meer muziek en wijs in dan dit elders b. v. op Java het geval is.

De Alfoer heeft verschillende zangwijzen, die elk hun bepaalde en soms zeer moeilijke tijdmat hebben, welke wijzen met hun tijdmaat, zonder dat er muziekanten van professie zijn of cenig bepaald onderwijs bestaat, echter zoo algemeen bekend 
zijn, dat een fout daarin den zanger aan de algemeene bespotting zoude bloot stellen.

Deze wijzen, die bij alle feesten en bijeenkomsten gebruikt worden, zijn de lolessa, de doppo-doppo, de rongo-rongo, de djomma, de djorree-djorree, de wella-wella en de tokkoe, die echter onder de rubriek vermaken behandeld zal worden.

De "lolessa" bestaat uit een solo-partij met invallend koor. Elk vers, dat uit vier of zes strofen bestaat, bevat telkens een op zich zelf staand verhaal; de voorzanger, tevens kapelmeester, begint met door drie statige slagen op den trom de aandacht te trekken en daarna op hoogen, dikwijls in fausset overgaanden toon te zingen:

$\mathrm{Ah}$, lee -- lee - mo-lee Een uitroep

S.

Tagi wangi remooi

To hottoe toma dowongi
Ik heb den ganschen dag (moeten) loopen en heb aan het strand geslapen.

Hierop volgt een slag op den trom, waarop het koor invalt:

To hottoe toma dowongi En aan het strand geslapen.

Bij een lolessa van vier strofen worden alsnu de twee eerste strofen door den solist herhaald en de 2e wederom door het koor gezongen; daarop vervolgt de zanger :

To nonoe fira mi loa

Mi loa se ma benari
(Het was mij om niets anders te doen dan) om een meisje te zoeken (met een) goed en oprecht (hart).

Het koor herhaalt daarop als slot de strofe

Mi loa se ma benuri

Goed en oprecht.

Een voorbeeld van een zesregelige lolessa is het volgende:

Solo.

Igo boela paramatta

Ahoe passi ma njekkoe.

KooR.

Ahoe passi ma njekkoe

SoLo

Ma boenga korree o gassa

Ma rau dorro dowongi

Koor.

Ma rau dorro dowongi

Solo.

Ma soffo dehe rimooi

Iroe kangatjee ngatjee

Kook.

Iroe kangatjee ngatjee
Solo.

Er stond een schoone witte kokospalm

In het zand op de kust

\section{Koor.}

In het zand op de kust

Solo.

De wind verstrooide hare bloesems;

Hare bladeren vielen in het zand

Koor.

Hare bladeren vielen in het zand

Solo.

Maar een vrucht dreef naar den landtong,

$\mathrm{Om}$ er bericht van te geven.

Koor.

Om er bericht van te geven.

Downloaded from Brill.com๑4/26/2023 02:58:58PM 
Het bovenstande vers is een toespeling op een jong meisje, dat op haren beminde wacht.

Vooral de Toebarezen ziju sterk in de lolessa, daar zij de zangen van hun voorvaderen bij overlevering bewaren.

De onderstaande lolessa bevat een klacht over het verval van den stam.

Siohanna ngeri jeuni

Dokka sosira ri oewa.

Djo wongi ori lefto

La fo akka dokassa.

Doenia ma rameni

Dikassi fo woeni bato.
Het is om medelijuen net ons te hebben, Want het is niet meer zoo als vroeger!

Helpt mij toch een lied maken, Want (zie), ik kan dat niet eens!

Vroeger wist men wel pret te maken;

Laat ons daaraan (in alles een voorbeeld nemen)!

Een andere lolessa bezingt eene sage en de macht der schoonheid.

Maligee dia ma oetji

Namo sella par matta.

Gabi mo tagi doenia Mo woeni Akkee Sengadji.

0 ra loellee se palang

Dokka dara to ma ngollo.
Er daalde een vrouw uit den hemel

Zij was zoo schoon als een phoenix.

Die vrouw ging op de aarde rond

En wilde den Akkee Sengadji bezichtigen.

Zelfs de maan bewoog onrustig (aan den hemel) heen en weer (toen hij haar zag)

Als een meeuw, die over de zee strijkt.

De lolessa, waarbij men altijd Ternataansch spreekt, wordt gezongen voor en onder het eten, als verpoozing bij de wellawella, den salei, enz. en bij den lego-lego.

De "doppo-doppo" is een beurtzang; hij neemt de plaats der maleische pantons in. De doppo-doppo wordt voornamelijk gebruikt voor liefdesverklaringen en om elkaar eens duchtig de waarheid te zeggen. De trom volgt daarbij den zang.

M MNNEN.

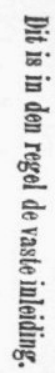

Djau tiffa maroewa Als Gij lieden den trom slaat Se ma biso djo ma mottee Zullen wij zingen.

Fo ma torari maroewa Wij zitten al tegenover elkaar Beso fo ma so si okko Dus Gij eens, wij eens!

\section{VROUWEN.}

Ngori ribo boela tiffa Mịn taak is het, den trom te roeren, Kangnganna ma doppo doppo Aan $U$ om de liederen te zingen.

Hitti no si booj bato Begint Gij maar eerst, Saha ngori to si gorro Dan zullen wij wel invallen. 
Madero ngoune nadj?dji

Vroeger hebt Gij wel afgesproken,

Goedoe maai to so njengga

Al was ik ver, toch zoudt Gij mij niet vergelen.

Madero fo borro ije

Vroeger hebt Gij met mij geaccordeerd

Lolena nganna se ngori

Gij zoudt het met mij houden (berkendah)

Nganna se ngori maroewa

Gij hebl met wij (voor van nacht) al afgesproken Si giki jali to hodoe

Denk er om, ieder ander te weigeren.
Nadjadji passa maroewa

Dat blijft afgesproken;

Goedoe maai tango nganna

Al zijt Gij ver, toch blijf its op $U$ wachten.

Madero fo borro ije

Die vroeger met u die afspraak gemaakt

Lolena giki roregoe

Was zeker iemand anders.

Nganna na mai laha

Gij niet, ook goed (voor u een ander)

To roeroe bolo to saai

(Zou ik daardoor) afdrijoen en zoek raken

(Denk niet dat mij dat veel schelen kan).

De bovenstaande verzen zullen wel voldoende zijn, om in het algemeen een denkbeeld van hetgeen deze meestal erotische liefdezangen behelzen; wat er zoo al onder het zingen en na afloop der zangpartijen, waaraan laat in den nacht meestal slechts de ongetrouwde jongelieden deelnemen, geschiedt, zullen wij hier ter plaatse maar niet meedeelen.

De "rongo-rongo" of "morro-morro" is ook een soort van doppodoppo, waarbij het echter minder op den geregelden beurtzang aankomt en elk vers meer een afgerond geheel vormt. Bij het zingen wordt met de vingers der rechterhand over het vel gestreken, waardoor het eigenaardig snorkend geluid ontstaat, waaraan deze zang den naam "rongo-rongo" te danken heeft; de maat wordt met de vingers der linkerhand geslagen.

Wij bepalen ons slechts tot eenige verzen.

Oekoe dia rongo

(Bis)

Toebaroe (bis) boloe Galelli
Het vuur rookt

(wie zit daarbij)

Toebarezen of lieden van Galella.

Redjadji (bis) talanga mooi (bis) Gij hebt mij (toenmaals) een armband beloofd Ali Ali poga njenga.

$\mathrm{Nu}$ heeft die armring nijn lart gebroken

Deze zang heeft eenige vermaardheid verkregen, daar hij in den Hassan-opstand als oorlogszang gediend heeft voor het overbrengen der berichten.

De "ljomma" is een afgerond geimproviseerd verhaal, dat, door den cen of anderen Alfoer vervaardigd, bij wijze van tijdkorting wordt voorgedragen en als het aardig is, door anderen overgenomen, de rondte makkt veelal hebben deze liedjes ten doel, 
het een of ander feit te releveeren of bekend te maken; als een staaltje volgt hier een der liederen, die door de van Gouvernementswege uitgezonden Alfoersche wervers werden gezongen, om humne landslieden van de onwaarheid der door de Ternatanen uitgestrooide geruchten te overtuigen.

Daai ma ngo ngadjee issa

Hera to sonuee

Habari gam goedoe

Hera to sounee

Faai koeboe toma Atjeh

Djerre Betawi

Paëssa toma Djoedja

Saya Samarang

Hera to sonnee

Bira no bobalo

Bobalo no holoe

I tokkoe de no tagi ka

I wella no ma roessa

No balo hono holoe

Daloa de no sonnee ka

Hera ngohi to bobalo

Totoetoe ta takkee.
Er kwam een bericht van over zee

(Het heette allen zijn) Dood en verloren!

(Zoo zijn de) Berichten uit een ver land

(Allen) Dood en verloren!

Ons graf werd op Atjeh gegraven;

Onze kramat (stond) te Batavia;

De doodsbloemen (haulde men) van Djokdja;

(Nog andere) Bloemen van Semarang,

(Allen waren immers) Dood en verloren!

$\mathrm{Nu}$ heeft mijn zuster geen man meer!

Maar zij wil geen weduwe zijn!

Zoodra de tokkoe (dans) gespeeld wordt, gaat zij er heen

Waar men wella wella geeft, zij is er bij,

Want zij wil geen (treurende) weduwe zijn!

Ja liever nog wil zij sterven!

Maar als zij (uit verdriet) sterft wordt de (nog

[levende man weduwnaar!

Klop (er eens tegen), bons (er eens tegen)

(Zoek naar de verborgen beteekenis).

In het eerste gedeelte van den zang wijst de zanger op de grove leugens en maakt die bespottelijk; daarop wijst hij er op hoe grif sommigen, vooral de achtergelaten vrouweu, die graag weder het jonge meisje willen uithangen, dergelijke vertelsels gelooven en brengt hun onder het oog, dat hun man nog wel degelijk leeft. Nog zij hierbij gevoegd een ander djomma van ietwat zedekundige strekking, echter onder een zeer omslachtig kleed.

1. Daai ma ngo ngadjee issa

2. O Kira ija sollo

3. Tikkee tikkee ma so sollo

4. Toma gosoengi

5. Tjellakka njao Bobara

6. Djofokatti sakko

7. Tiffo ika Tiffo ino

8. Dadi fiaro

9. Ihadja katta kaboekka

10. I toerakoe ta tidee

11. Bobosso toddo mottoe

12. Doemmee ta tanee
1. Ik kom zoo uit zee

2. De Kera (kleine vischsoort) ging de rivier op

3. Ik zocht naar hem, de rivier al opgaande

4. In het riet. (Toen zag ik het)

5. De Bobara (grootere vischsoort) zat bem achter na

6. Hij dreef hen uit elkaar

7. (schielijk) Heen en weer snellende

8. Alles vloog (dan ook) uit elkaar:

9. Een mensch verzamelde ben (de visschen)

10. Toen zij (door den schrik gedreven) op het strand

11. Hij deed hen in een pot [vielen

12. En zette hen op den riggel (van zijn huis) 
13. No sari na makewa

14. Makka hikka Makka himo

15. Kamo parra sadja
13. (Iemand anders) die ze ook hebben wilde zocht er

14. Hij keek overal rond [uaar;

15. (Maar vond ze niei). Het was alles nevel.

De "djorree-djorree" is een bepaald aan het landschap Kau eigen beurtzang, bestaande uit mannen en vrouwenkoren met solo-partijen voor beiderlei kunne; bij wijze van tegenstelling hebben deze met zachte stem meestal piano of dolce gezongen liederen, eigenaardige, lieve, hoewel ietwat monotone melodiën, welke, wanneer men ze in de rechte omgeving, dat wil zeggen in de diepe wildernis, des nachts, door de bij het rossige schijnsel van een groot vuur zittende koren hoort voordragen, een vreemdsoortigen, lang niet onaangenamen indruk te weeg brengen.

Men kent daarbij drie verschillende wijzen en wel de djorree djo, de dorou goellee en de waai donnee, welke laatste voornamelijk als eerbewijs gezongen wordt.

KOOR DER MaNNEN.

Lelee molelee ijo (uitroep)

Solo.

Lakkoe tago le-oe ika

Ik zie van hier met mijn beide oogen

Dakka dara nagee oena

Mijn hartje daar zitten;

Ma pakee ma leketto

De kleeding, die zij aan heeft

Ma tekee toeroe tjena

Is oh zoo schoon!
KoOR DER VRouwen.

Njorree djo njo (uitroep)

Solo.

Mooi ino la totoeo legoe

Kom zet $u$ neder om te zingen

Si mokkoe ri benari

En gebruik op $U$ gemak dsn pinang;

Regoeroe mossi wa wassoe

Mijne moeder dat moet ik zeggen,

Na ngassee ngari ma dogoe

Wil niets van onze verkeering afveten.

Koor. (Bis).

M. Lelee molelee ijo

V. Njorree djo njorree ijo.

Koor $\left\{\begin{array}{l}\text { Daai mangon ngadjie issa } \\ \text { Het bericht moet over zee komen } \\ \text { Dara dakka nagee oena } \\ \text { Dat ik Uw schat ben } \\ \text { Mommi to njing ngadjee ngadjee } \\ \text { Wordt wakker door mijn zingen } \\ \text { To njing ngadjee ngadjee mala } \\ \text { Wij zullen een weinig met elkander keuvelen. }\end{array}\right.$

De "wella-wella" behelst de liederen, die bijna uitsluitend bij het rottan trekken door de jongelieden gezongen worden en kan dus, hoewel dit eigentlijk onder de rubriek vermaken behoort, moeilijk opgenoemd worden, zonder tevens vermelding van den loop van dit meer eigenaardig Galellasche zangspel te 
maken, dat meestal op de begrafenisfeesten ter eere van den doode, enz. gehouden wordt.

De wella-wella bestaat in het trekken van een lang rottantouw door twee partijen, eigentlijk mannen en vrouwen, welke laatste echter dikwijls door eenige galants geholpen worden. Het voor-, tevens zangspel heeft hierbij echter de hoofdrol. Het spel begint daarmede dat meestal eenige jonge meisjes, soms ook eenige jonge mannen beginnen met den langen rottan op te nemen en onder een vlugge maat van tiffa en gong de jongelingen, die dadelijk toeschieten, opwekken hunne krachten te beproeven; deze opmarsch, om zoo te zeggen, is werkelijk niet onaardig en er ontspint zich daarbij een beurtzang tusschen de jongelui, waarin allerlei dingen gezegd worden en sub rosa of vrij duidelijk allerlei minder zedekundige verhandelingen plaats hebben. Telkens laat daarbij het een of ander jonge meisje het touw los en huppelt in de handen klappende bij wijze van plagerij voor de mannen heen en weer en keert daarop juichende bij hare speelgenooten terug; ook de jonge mannen begeven zich op die wijze tusschen de jonge meisjes in, leggen daar hun handen op de schouders van hun uitverkorenen, zoenen haar en rooven haar de bloemen uit de haren; met de duisternis wordt dit veelal minder onschuldig en loopt dan ook dikwijls een zoogenaamde valsche handgreep daar ongestoord onder door.

De wella-wella begint in den regel met den volgenden zang.

Oh wee oh wella wella

Oh wee oh wella wella.

\section{JongeLingen.}

Sabi mooi Sabi mooi

Twee menschen (bis), Sabi mooi si a fera

Twoe menschen, waarvan een een vronw is Matemo dalo loha

Kunnen yoed met elkaar praten.

Odji alpan to ossa

Bruidje wees niet boos,

To ossa ngohi kaai modo

Wanneer ik bang ben, om te trounen!

To ni modo loa ali

Niet dat ik bang ben voor de vrowoen, To ni singow lo to holoe

Ze zijn mij onverschillig;

I bargoena loa ali

Ik heb niets met hen noodig!
MeIsJes.

Sabi mooi a wella wella Twee menschen aan het trekken

Sio hoea wella wella

Een zuster (vrouv) aan het trekken

Doloa walo kano temmo

Als het niet mooi is, moet Gij het maar zeggen

$\mathrm{O}$ kia podo ossa

Wie is er boos?

Kia no modo wella wella

Wie is er bang om te trekken?

No i modo, wella wella

Ja wel Gij zijt bang, trek maar!

No singow wella wella

Ja wel Ge geeft wel om hun, trek maar!

Baragoena wella wella

Ja wel Ge hebt hun noodig, trek maar! 
Hottoe tobbo loettoe loettoe

Il lag in diepen slaap;

Boloettoe wangi boloettoe

Een heelen dag had it vast liggen slapen;

Nanee mari ketto ketto

Ik droonde (toen) het was alsof iemand mij

To issee djo-oe no tiffi:

[wakker
hoorde.

(eii) ik (op eens) woe trom hoorde.

Togorakki si to mommi

It verschrol en stond op,

Toma roekoe sito tagi

Maar ik wist niet waar ik heen mogt gaun;

Todera wa ngokko wa

Il vond den weg (maar) niet

Tama toroe to genado

Ik ging (dus) terug en informeerde

To genado sengo goeroe

En vroeg aan een oud man,

Songo bokki paramata

Waar zijn toch die beeldschoone meișjes?

Ngokko ma so sella doffoe

de veg heeft zoovele takken,

Ma lo linga liba liba

En slingert zich heen en weer.

Goebadi no mottee affa

(De man zeide) Houd vooral niet links aun,

Goenera no mattee bato

Den rechtschen weg moet Gij kiezen,

Mottee ngokko loa loa

Volg maar den goeden voeg,

Loa loa ngossa dinee

Ga maar recht landwaarts!
Boloettoe ma wella wella

Fast slapen (en komen) treklien!

Boloettoe ma wella wella

Vast slapen (en komen) treklien!

Ritta Ritta ma w.w.

Wakker gemaakt (konen) trekken!

Tiffa ma w.w.

De trom oan het wolla wella.

No mommi ni w.w.

Wakker worden (en komen) treklken!

Totagi ma w.w.

Uitgaun (om te) trekken!

Ngokko ma w.w.

Den weg naar het wella wella!

Genado ma w.w.

Vragen naar het trekken!

Ngogoeroe ma wella wella

Den ouden man zijn wella!

Paramata ma w.w.

Het buitengewoon schoone vella wella!

Doffoe ma w.w.

Veel heen en veer trekken!

Liba liba ma w.w.

Heen en weer trekken!

Mottee offa ma w.w.

Doe niet mee an het wella!

Mottee bata ma w.w.

Doe maar mee met het trekken!

Loa loa ma w.w.

(Vooral) goed trekken!

Kodadee ma w.w.

(Neen) zeeroaarts moet er getrokken worden!

Hierop antwoorden de meisjes in den regel met het volgende vers :

Dahoe ma lolinga ije

Saija Baltako

Ma silori kamanoeroe

Mossi ran Dagasoeli

Mossi to tolla lebo dadoc

Ook ik ben straks van beneden (het strand) naar

[boven (het dorp) gegaan

(Ik heb mij versierd met de) bloem van den Bintangor Vermengd met die van den Melati-struik

Watarbij ik de Dagasoeli bloem-gevoegd

En er de Kembang sěpatoe naast gestoken heb.

De meisjes wijzen in dit vers op hun opschik, want ook hièr heerscht het bij de meeste inlanders gehuldigde denkbeeld, dat kleeren den man, in dit geval de schoone maken.

Hicrop volgen tal van plagerijen, minneliederen, minneklachten enz vap welke hier als voorbeeld slechts dat van 
een pruilenden en min of meer teleurgestelden minnaar gegeven wordt.

Boerong laui to mottec

Tarokan soa njehee

Tabani lelle nigara

To ramee seni kadato

Ramee dokka djo-oe baai

Sengori ma dodjo wa

Djollo wakko to koeliko

Dokkoe doro $\mathrm{ka}$ to liho.
Als cen meeuw (woord. met de mecuw) ben ik her[watarts gevlogen

(Eerst) langs het huis (gaande)

(Bleef ik) voor de deur heen en weer draaien.

Daar in huis is alles vreugde;

Meu viert feest en de meisjes zijn zoo schoon.

Maar helaas! mij willen zij niet!

Het is veel beter, dat ik terugga,

Naar het akelige dorp (waar ik van daan ben).

Thans begint het oogenblik van het trekken te naderen.

De tiffia geeft een snellere en kortere mat aan; de bewegingen worden vlugger, de wendingen telkens kleiner; de vrouwen beginnen daarop den slotzang:

Sabi mooi Sabi mooi

Sabi mooi sio-fira

Matimo dalo loa

Oedji opan to ossa

Tjakko tiffa djo boboho

Massi daai fo ma badoe

Pana wa to si mottee

Lakkoe ngini Keke ngini

(Komt) de lieden zijn al moe van 't tiffa slaan

(Komt) laat ons eens probeeren te trekken

Wie het niet kan zal verliezen

Als Gij (mannen) het wint, moeten wij (vrouwen

[u volgeu

Lakkoe ngomi Keke ngami

Winnen wij (vrouwen) het, moet Gij (maunen) met

Hira opa no ma badoe

Bira ngomi mi kangella

Hira kia koma ngenna.

Daloa de no somnee ka

Dalo ngohi to bobalo.

[ous mee

Trek toch vooral niet te hard, broeder?

Anders wordt Uwe zuster te vermoeid!

Wat is dat dan ook voor een broeder (die zoo doet)!

Liever sterf ik, (ja)

Liever wordt ik weduwe (dan zoo iemand tot man

[te hebben).

Hierop roepen de vrouwen : "Oh wella matabea ajo-oe linanna", waarop allen antwoordden: "Oh wee oh wella" en onder het geschreeuw van "au-oe-leelee" door de mannen en "tjoe loeloeloe" door de vrouwen, een trekken aan den rottan begint, dat soms pas met het scheuren van den rottan eindigt.

In den regel echter gelukt het de eene partij, nadat de uitslag een tijd lang weifelend geweest was, een aanloop te nemen, als wanneer het hoe langer des te gauwer naar die zijde toegaat en het voor de tegenpartij onmogelijk wordt weder vasten voet te krịggen; veelal ziet men dat juist de zoogenaamd zwakkere kunne het wint. 


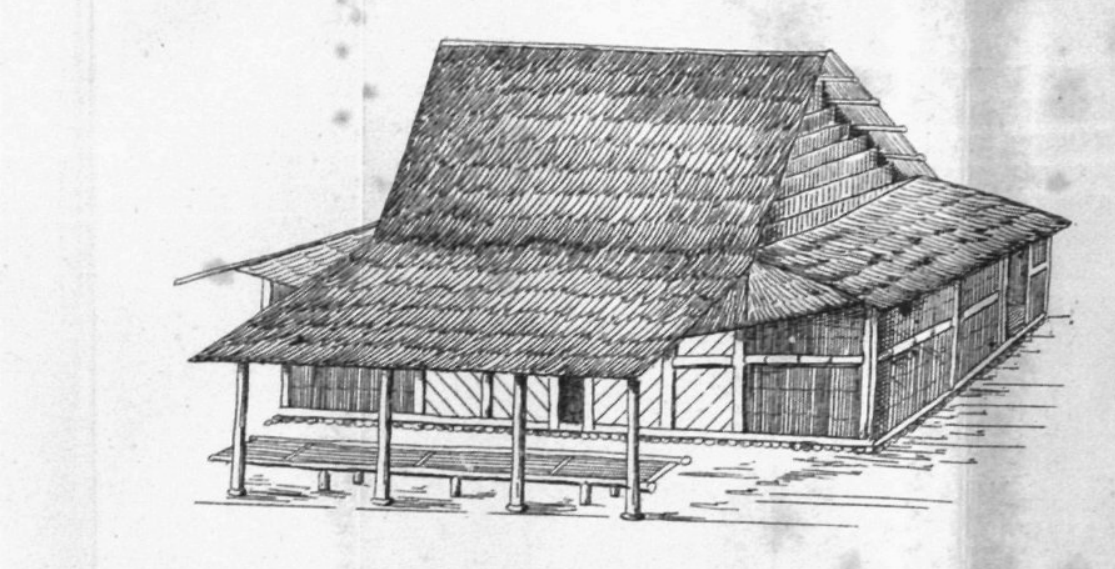

Fig. II

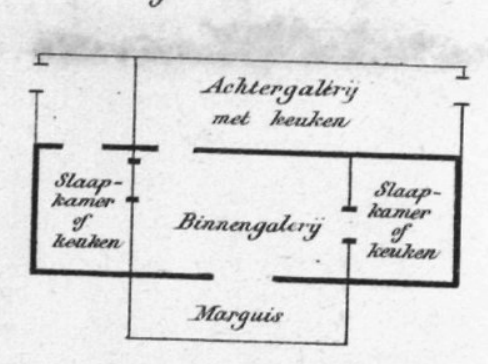
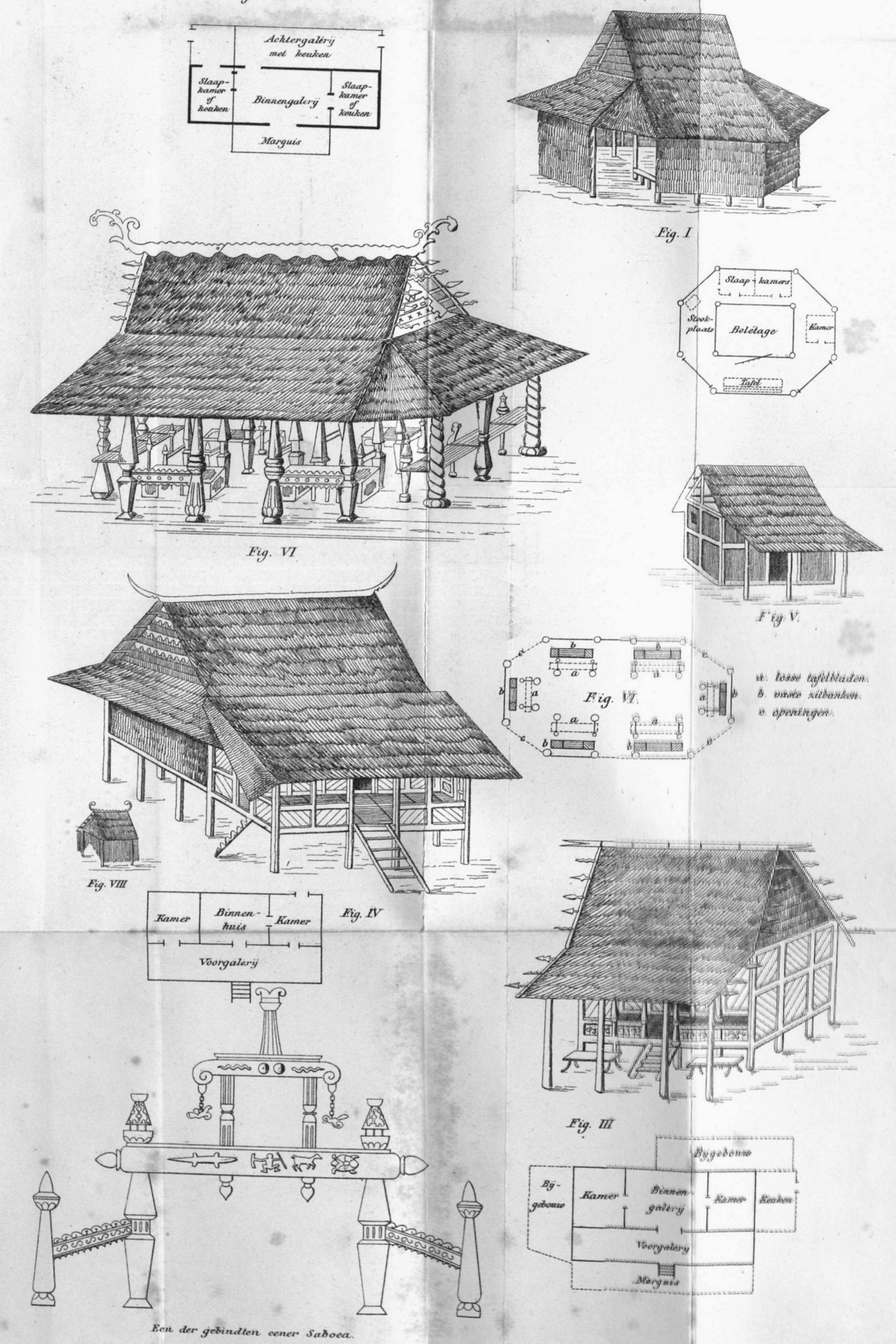

fig. I 
PLAAT II.

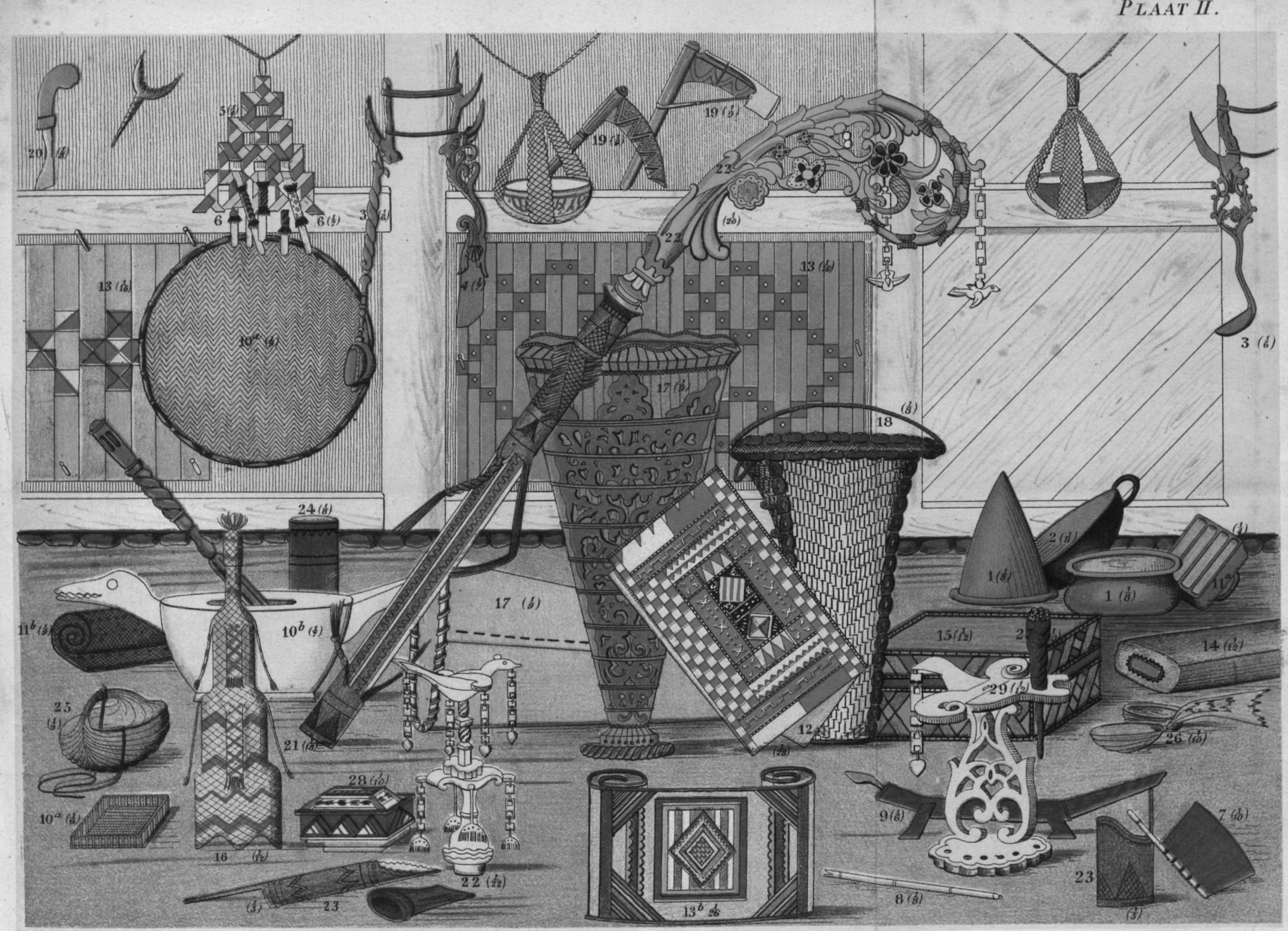




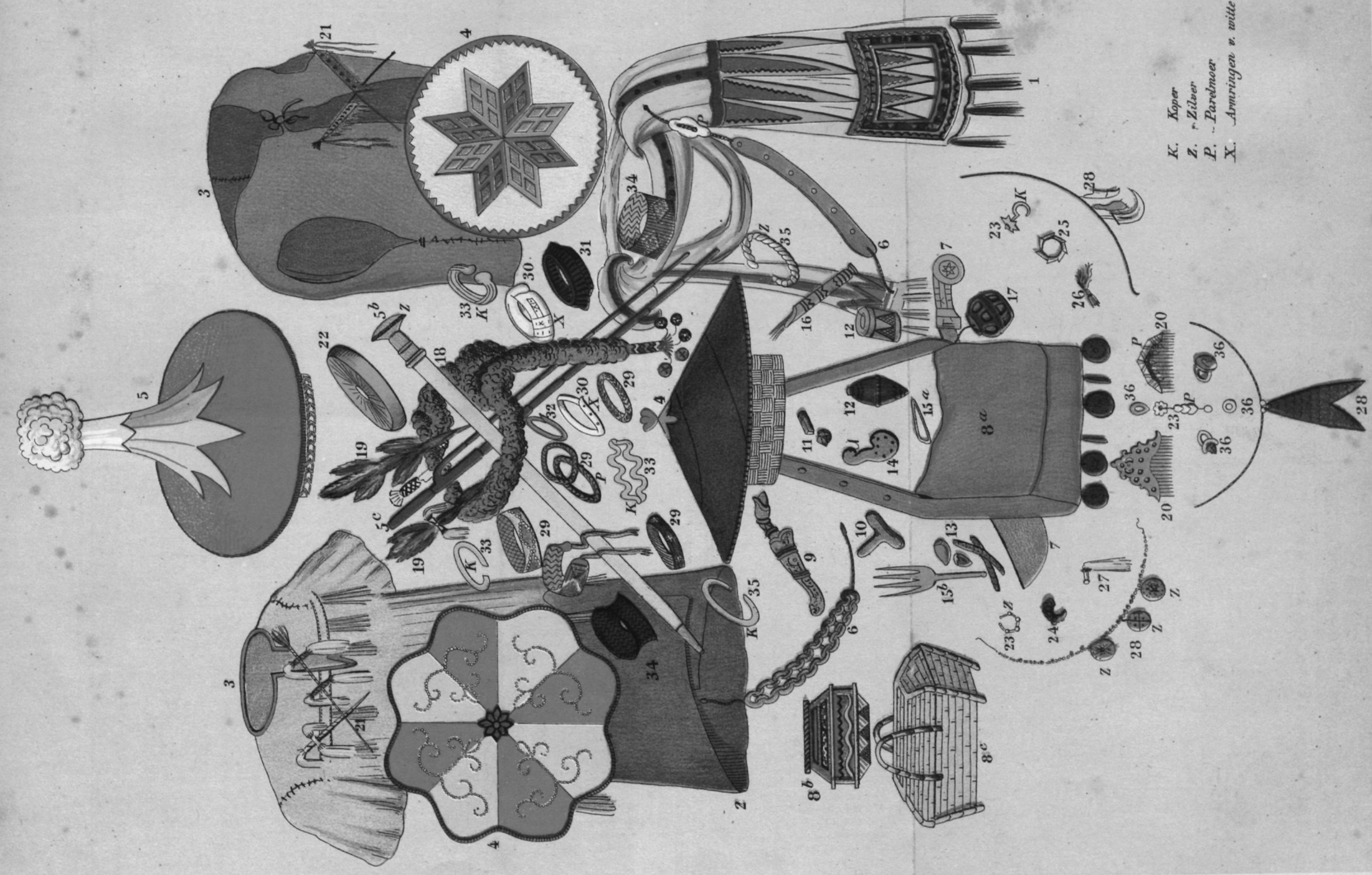




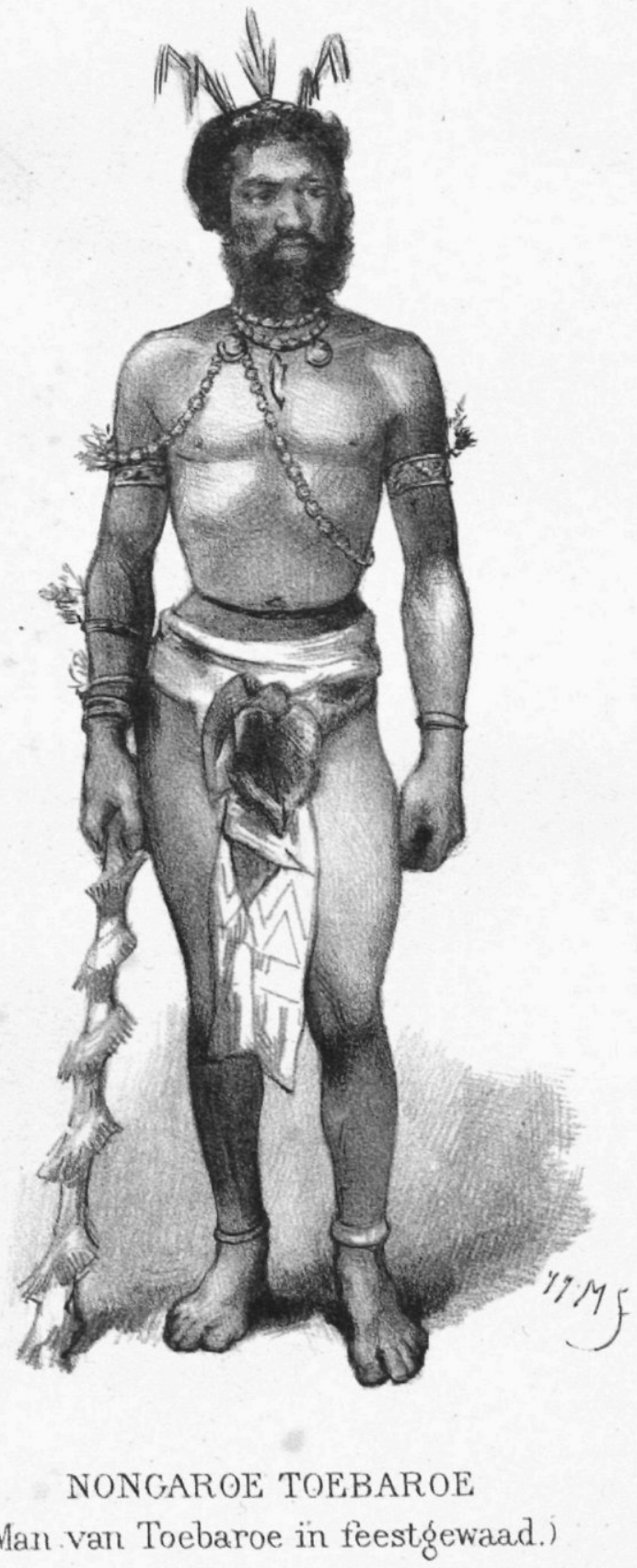

Downloaded from Brill.com๑4/26/2023 $02: 58: 58 \mathrm{PM}$ via free access 
PLAAT IV.

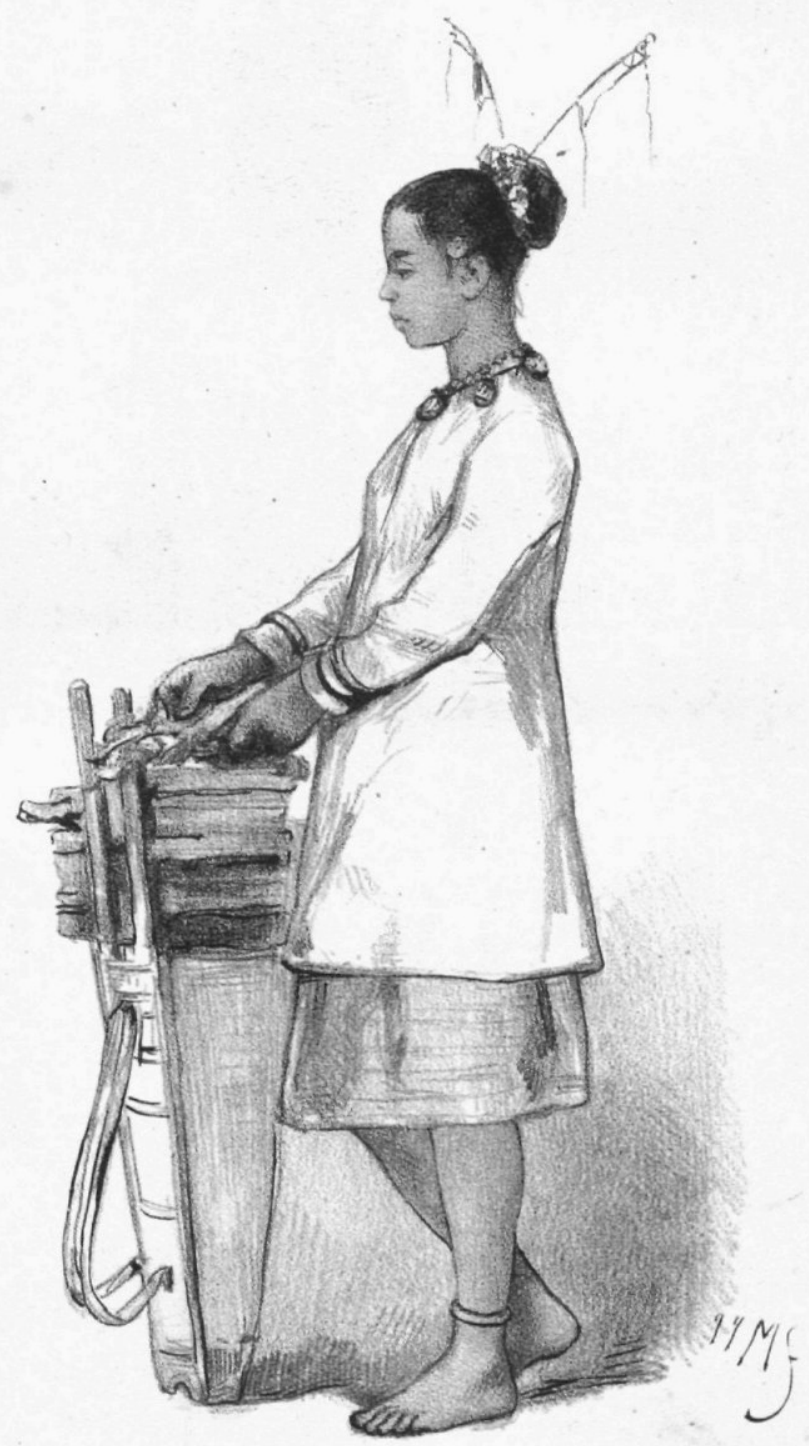

DJODJAROE GALELLA

(Jonge dochter van Galella in feestgewaad.) 


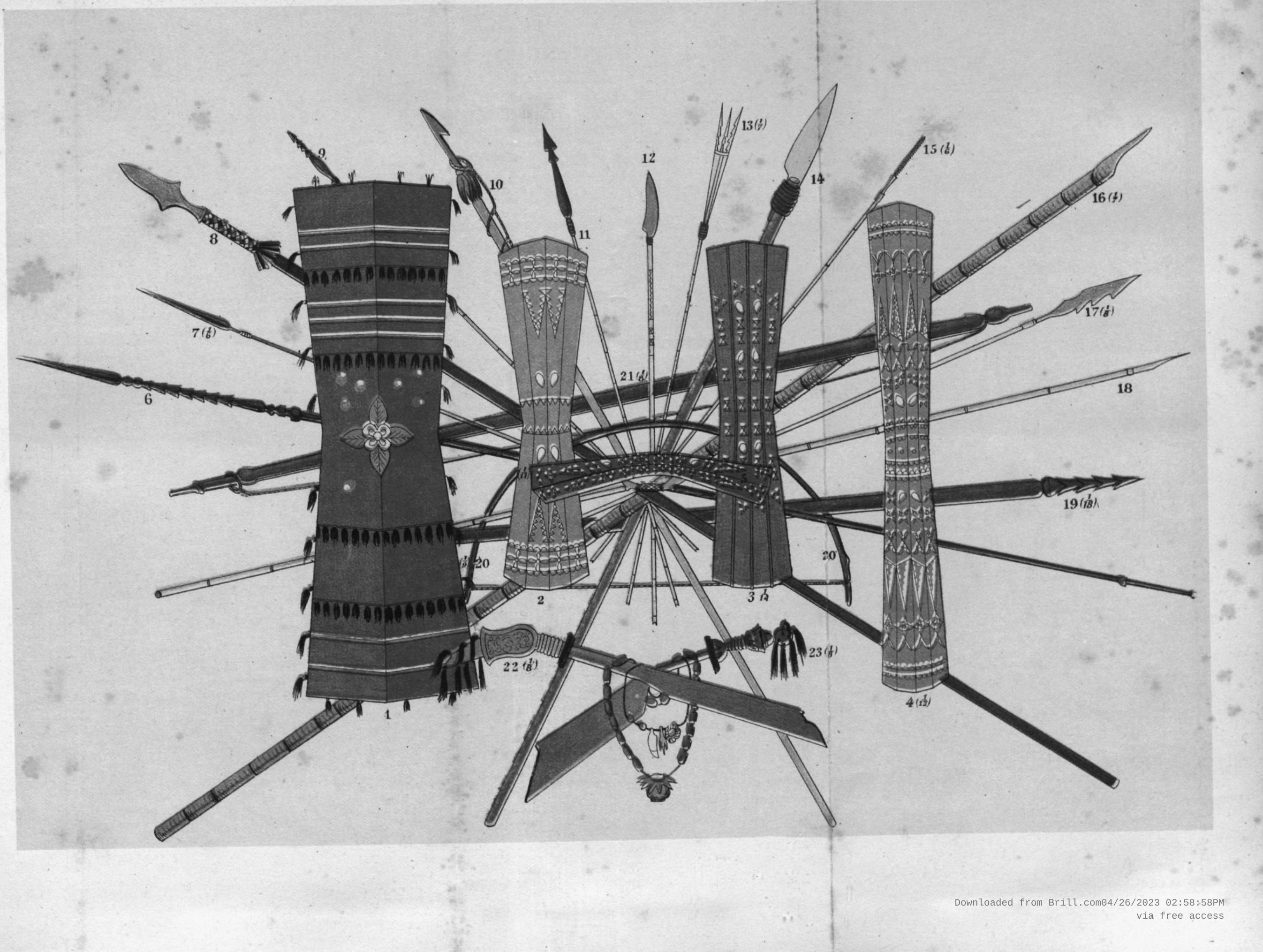




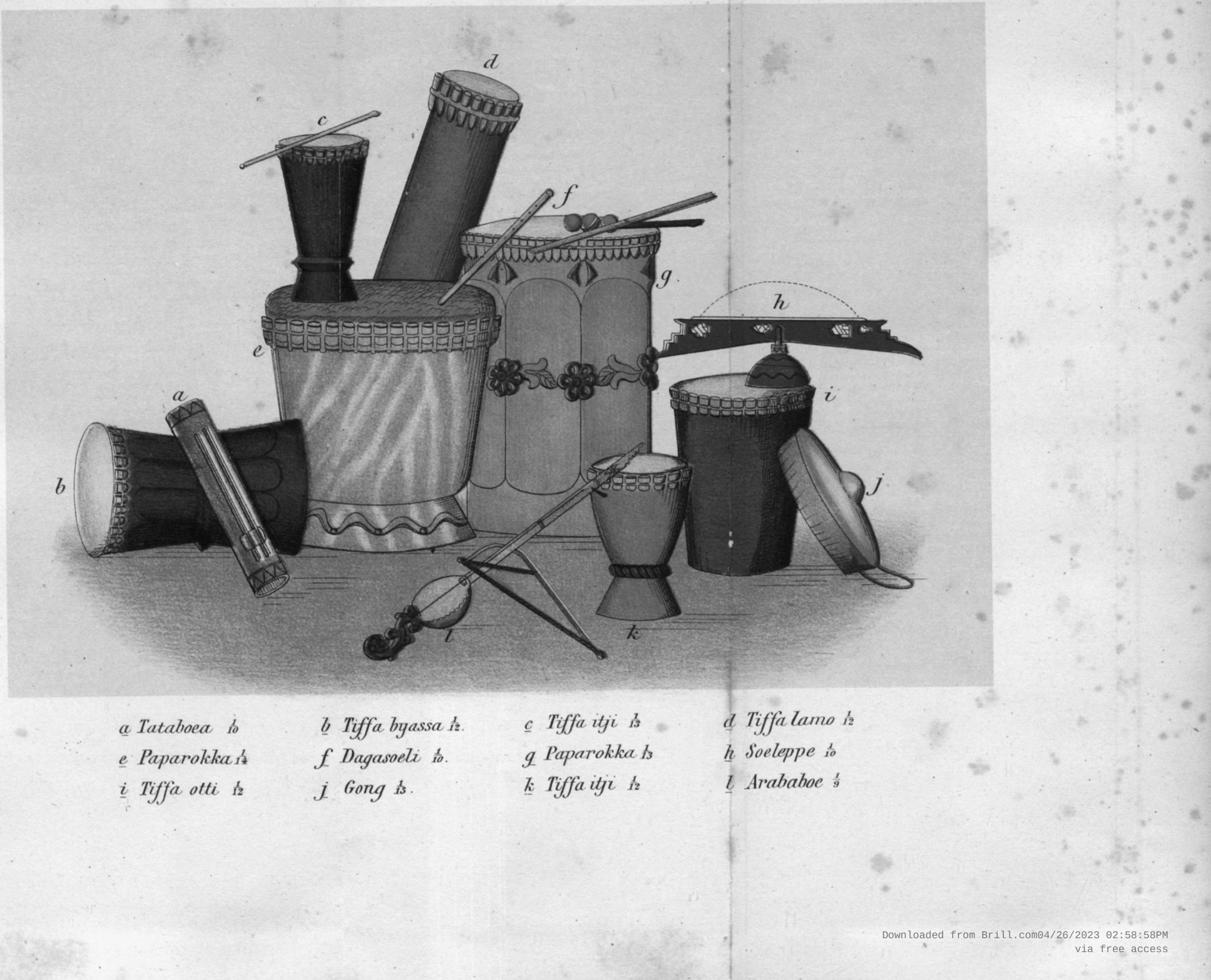

